\title{
Blended learning citation patterns and publication networks across seven worldwide regions
}

\author{
Kristian J. Spring and Charles R. Graham \\ Brigham Young University
}

The field of international blended learning (BL) is primed to benefit from stronger communication and collaboration. Collaboration is currently limited, and regions vary greatly in terms of citations. However, BL is growing worldwide and each region is an important part of the community. The goal of this research is to explore where the most impactful conversations about BL worldwide are occurring and how, if at all, are they connected to one another in terms of citations and publications. We present here the most cited BL articles from each region, the journals that publish these articles, and citation and publication patterns for each in order to construct a broad overview of impact and publication within the field.

\section{Introduction}

Research conducted in 2012 by Halverson, Graham, Spring and Drysdale located the most frequently cited articles discussing blended learning (BL), many of which were familiar to us as North American researchers. We noticed that although several publications were connected to regions other than North America, only four of the articles, fewer than 5\%, addressed international issues (Halverson et al., 2012). Another project exploring theses and dissertations found only two (1.0\%) with an international focus (Drysdale, Graham, Spring, \& Halverson, 2013). As the world extends considerably beyond North America, we hoped that the world of BL extended further that these initial results might suggest. We sought to learn more about BL outside of North American and benefit from advances by researchers worldwide. Coming from the United States we have inherent biases and familiarity with our own region, but have strived to collect and analyse the data as objectively as possible. In the current study we focused on the most frequently cited articles on BL in each region of the world. Our goal is to understand which articles from each region are the most cited, how the regions compare in terms of citations and which journals publish these highly cited articles in order to construct a broad overview of the field as a whole.

For the purposes of this research we use the broad definition of BL as systems combining face-to-face and computer-mediated instruction (Bonk \& Graham, 2006). There is much disagreement on the precise definition of BL (Bernard, Borokhovski, Schmid, Tamim, \& Abrami, 2014). Concerns include a reduction in seat time, the proportion of online learning to face-to-face instruction, and the quality of the learning experience (Graham, 2013). A vague definition can be useful as it provides space for adaptation to specific needs and contexts (Graham, 2013; Norberg, Dziuban, \& Moskal, 2011). We chose this broad definition to avoid limiting the "great potentials of the concept" and to be as inclusive as possible to difference conceptions of blending around the world (Alammary, Sherad, \& Carbone, 2014; p. 443).

As Bonk, Kim and Zeng found in 2006, BL is a field of ongoing concern. We submit that it is therefore valuable to analyse connections between regions and researchers. Bonk, Kim, and Zeng (2006) surveyed instructors and administrators at institutions of higher education primarily in North America, as well as corporate training professionals about the "current status and future trends" (p. 552) of e-learning in their areas of expertise. They received $562(\sim 4 \%)$ and 239 replies respectively. The low return rate was tempered by a relatively large supply of total responses. At that time $93 \%$ of post secondary respondents indicated they were blending their instruction, with more than $60 \%$ blending in no more than $20 \%$ of their courses. These individuals predicted their use of BL would progress further, with more than $70 \%$ expecting that more than $40 \%$ of their courses would be blended by 2013. Respondents working in the corporate world supplied similar answers: $86 \%$ were blending their teaching, and about $60 \%$ expected that more than $40 \%$ of their courses would be blended by 2013. Bonk et al. (2006) suggested that these findings indicated BL is a long-term trend rather than a passing fad. So far this has prediction has been correct. 
BL has been found throughout the world in recent years, but has not yet been analysed or compared quantitatively worldwide. In 2011 Barbour surveyed education researchers in over 60 countries about trends in K-12 online and BL, receiving 50 completed surveys. Summaries of nine purposively sampled case studies submitted by online and blended learning researchers in diverse countries also contributed. The sample was small but varied. Barbour et al. found that, (a) blended options are more available in urban areas of developed countries; (b) specialised professional development for teachers is encouraged but not required; and (c) BL is occurring much more often than online learning. They discovered inequitable access to technology and funding, as well as a need for more training for online and blended teachers. While there are intriguing global and local conclusions, we are interested in looking at each region more quantitatively and in terms of publication.

Researchers have found it useful to examine regional issues related to BL, but have not yet looked at the field on a large scale. Tham and Tham (2013) examined the state of BL in Asia, reviewing literature on challenges to blended and technology mediated education in four Asian countries: China, Japan, South Korea, and Singapore. These countries provided a limited view of the situation in Asia as a whole, and selection criteria for the literature were not described; however prevailing challenges were documented, including issues related to culture and to pedagogy and design. Cultural issues included teacher dependency in China, tell and listen strategies in Korea, and non-Western learning and teaching styles in Japan. Pedagogical and design issues included competition in China, lack of interaction in Korea, and limited Internet use in Japan and Singapore. Learning about regional issues has been compelling for the BL community in Asia, as it promotes collaboration over shared concerns. We suggest that a look at BL across the world can prepare the field for more research on individual regions such as this, as well as providing a useful way to look at the complete field of BL.

Research has been conducted to look at the most impactful research in BL overall, but not with a focus on specific regions of the world. In the earlier inquiry we found that BL research has shifted from a descriptive to an empirical base. Halverson et al. (2012) compiled a list of the 50 most impactful articles on BL based on Google Scholar citation counts. We found many of the most frequently cited but older articles focus on definitions or future growth. We also collected a list of newer articles that are frequently cited but have not had sufficient time to accumulate as many citations as the older ones. The fledgling articles focus less on defining $\mathrm{BL}$ and more on empirical research, indicating a transition of interest. This research disregarded geographic origin, but we noticed that most of the highest cited were by North American authors. Articles written by authors outside of North America tended to originate in Europe, with a small number from other regions. We suspected that other regions were underrepresented; the current research project sought to describe the state of $\mathrm{BL}$ worldwide, comparing the various regions.

\section{Research questions}

Our exploration centered on this query: Where are the most impactful conversations about BL worldwide occurring and how, if at all, are they connected to one another? We sought to answer this question in terms of citations as well as publications using the following specific research questions:

1. Which are the most frequently cited articles worldwide as determined by Google Scholar?

2. How do the highly cited articles from each region compare in total citations and their origins?

3. Which journals publish the most highly cited articles on BL worldwide?

\section{Methods}

We surveyed research articles on international BL to determine the most frequently cited works in each region. We compiled a list of the 10 most highly cited research articles in each region and compared them (Research Questions 1 and 2). We then conducted a social network analysis on the top publications and the works that they referenced (Research Question 2) and listed the journals that published the most cited articles (Research Question 3). 


\section{Searching and selection procedure}

We searched for a broad set of terms in several databases, hoping to catch as many articles as possible. Afterwards we narrowed the pool with specific inclusion criteria.

\section{Source of publications}

We used the Education Resource Information Center (ERIC) as the primary search database because of its wide range of offerings on education literature. ERIC provides access to over 1.4 million records dating as far back as 1996 (ERIC, 2014). To be more thorough, we also searched in Academic Search Premier, Business Source Premier, Cumulative Index to Nursing and Allied Health Literature (CINAHL), and Education Full Text (H.W. Wilson). These databases were selected because of their high numbers of returns when searching all EBSCO databases, and because they enabled us to sample a wider variety of topics since BL is practiced frequently in business, health, and other disciplines in addition to education (Halverson et al, 2012).

\section{Search terms}

Because BL is present in a wide variety of works and is conceptualised several ways, we first ran a broad search of related terms using limiters to restrict irrelevant findings. Applying the ERIC thesaurus function, we searched for broad educational technology and distance education descriptors in the ERIC database. We added specific BL phrases to the primary list for a search within titles, abstracts, keywords, and descriptors in Academic Search Premier, Business Source Premier, CINAHL, Education Full Text (H.W. Wilson), and ERIC:

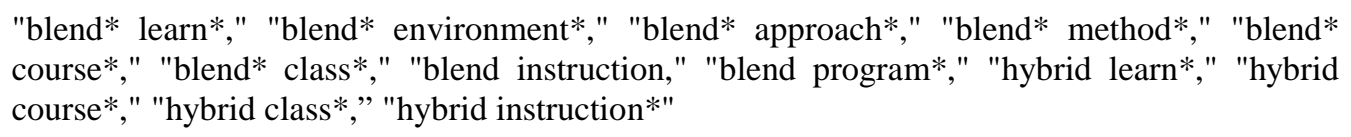

We combined the search for BL terms with a search for regional terms, dividing the world into seven regions: Africa, Asia, Europe, Latin America, the Middle East, North America, and Oceania, as shown in Figure 1. We began delineating regions based on the United Nations' composition of regions (Indices \& Data: Human Development Index [HDI], 2011) and separated some further along cultural and linguistic lines. We included Mexico in Latin America though it is part of North America because it is a Spanish-speaking nation. We separated out Western Asia from the rest of the region and referred to it as the Middle East because we felt it was culturally and linguistically distinct enough to be examined singly. We ran a separate search for each region except North America, including country names included in that region as well as the name of the continent and/or region. In some cases we added or substituted short form names (e.g., searching for both Democratic Republic of the Congo, and Congo). We searched for these terms within the full text to catch any mention of author affiliation (e.g., university) or the location of a research site. We limited each search with blended terms: blend*, hybrid* or (online AND face-to-face) to narrow the returns to those most likely to be relevant. We also consulted the list of highly cited articles from Halverson et al. (2012) to ensure that none of those articles was overlooked. That list supplied the 10 most cited articles for North America. 

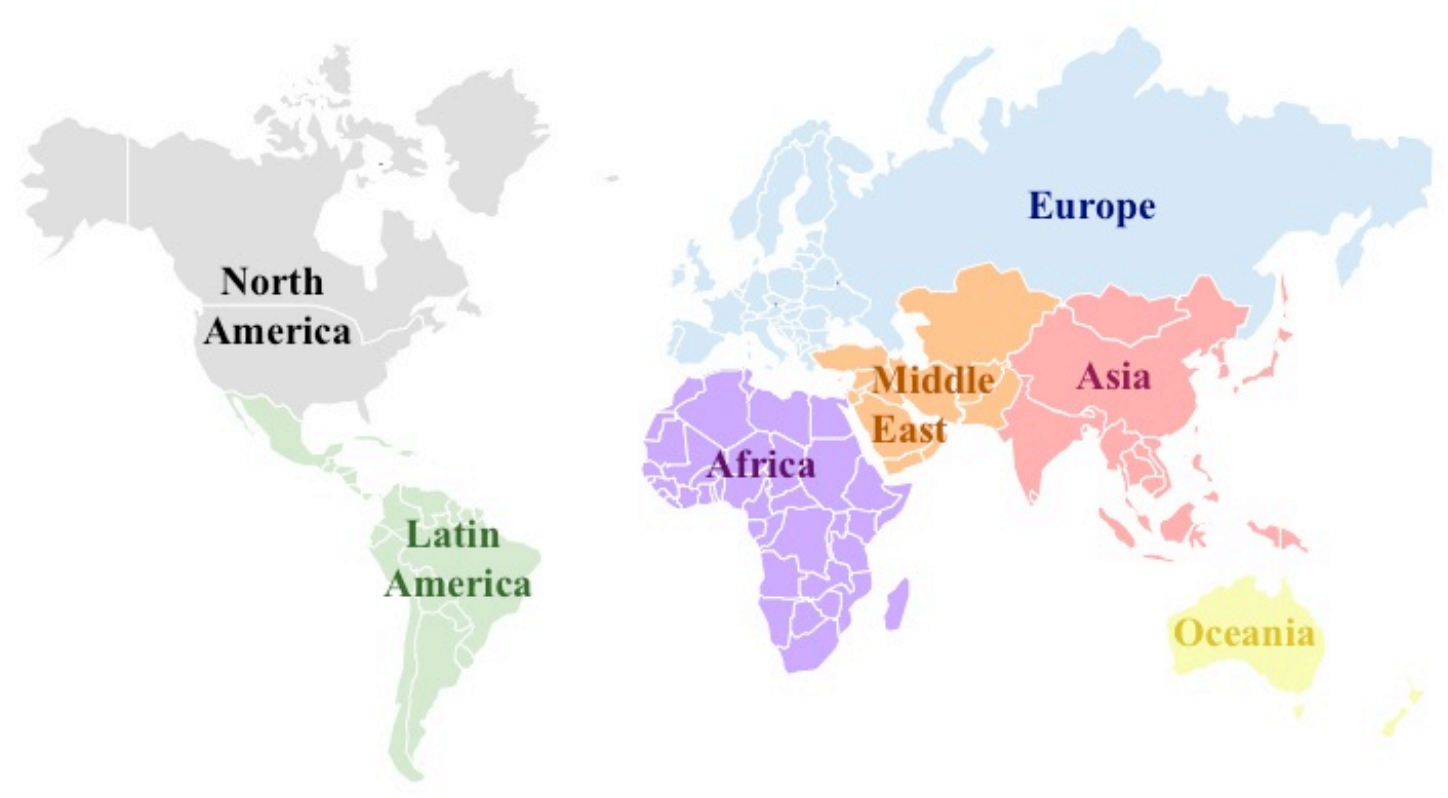

Figure 1. Countries included in each region. Created with template from Presentation Magazine.

\section{Inclusion criteria}

Searching a wide range of databases, we retrieved many articles unrelated to BL. We excluded articles outside of our definition of BL as described previously as well as those in which BL was not a central point. When the primary researcher was unsure, another researcher was consulted.

We evaluated each return for relevance based on the following inclusion criteria:

1. Article in academic journal,

2. Article in English,

3. Article with BL as a central topic,

4. Author or study site in one of the six regions, and

5. Use of the terms blended or hybrid.

Each relevant publication was then located in Google Scholar to determine its number of citations as of 18-21 June, 2013. Because of the large body of articles the search took several days. While some publications may have gained a few citations in that time we feel any gains in such a short time would be negligible when examining these patterns. We then updated the most cited lists and citation counts on 10 March, 2016. We ranked publications by citation count to determine the 10 most cited in each region. A separate category was created for works spanning more than one region, as they had been discovered through examining other lists of returns. Our final list included 76 most cited publications: 10 each from Asia, Africa, Europe, the Middle East, North America, and Oceania; six from Latin America (the total number of retrieved publications that fit the inclusion criteria); and 10 connecting multiple regions.

We restricted the study to English articles because the researchers are fluent only in English and could not properly identify or analyse articles in other languages. We acknowledge unfortunately missing a portion of the 
community because of our linguistic limitations. Across disciplines however English is the most common language of academic publishing (Belcher, 2007) as well as scholarly citations (Breeze, 2015). We anticipate that our research may help highlight works that, although written in English, are less widely acknowledged because they focus outside of the Anglophone center (Curry \& Lillis, 2004; Lillis \& Curry, 2010). Furthermore, we included only articles using the terms blended or hybrid because we were interested in the happenings of the specific BL community, which we perceive as centering on these terms. Even authors who raise meaningful concerns with the term blended (e.g., Oliver \& Trigwell, 2005) continue to use the term, presumably because it is still used by others in the conversation (e.g., Holley \& Oliver, 2010). If authors considered themselves part of the BL field (by virtue of using the terms blended or hybrid), and made BL (by the broad definition of combining face-to-face and online learning) a central tenant of their work we included their articles. Our criteria were set to be as inclusive as possible, while drawing some parameters around the view of the BL community we took.

\section{Social network analysis}

We catalogued the references provided by most cited articles and determined the in-degree of each one (Kilduff \& Tsai, 2003). In this study the in-degree is the number of times an article has been cited by others in our most cited lists. We focused on in-degree because it is indicative of citations by highly cited articles, and therefore, we submit, influence within the field. Our unit of analysis was each most cited article, all of which supplied all references, therefore we conducted our analysis based on whole network data. Each publication was assigned an identification number and level. The initial 76 articles that were the 10 most cited for each region constitute Level 1, while those that they cited comprise Level 2. Any Level 1 publications cited by another Level 1 publication retained their initial level. We compiled a list of connections (a tie list) linking each publication and those it cited so we could determine which if any references were cited by more than one of the 10 most cited publications. Finally, any article cited by two or more most cited publications was located and assigned a region of origin based on author affiliation. We selected author affiliation as the deciding variable because this analysis was focused on citation practices and therefore on contact among scholars themselves.

\section{Results and discussion}

In order to present an overview of the current field of BL research we analysed our included articles to determine the most cited articles and their origins, inter-regional citation patterns and most included journals.

\section{Most cited articles}

We collected the 10 most cited articles from each region except Latin America (as we found only six articles from Latin America that met our criteria). An article was grouped with a region based on, (a) the affiliation of the author(s) (e.g., university, company), and/or (b) the location of the research site or focus. The full list of most cited articles is available in Appendix A. Figure 2 below represents the two most cited articles from each region. 


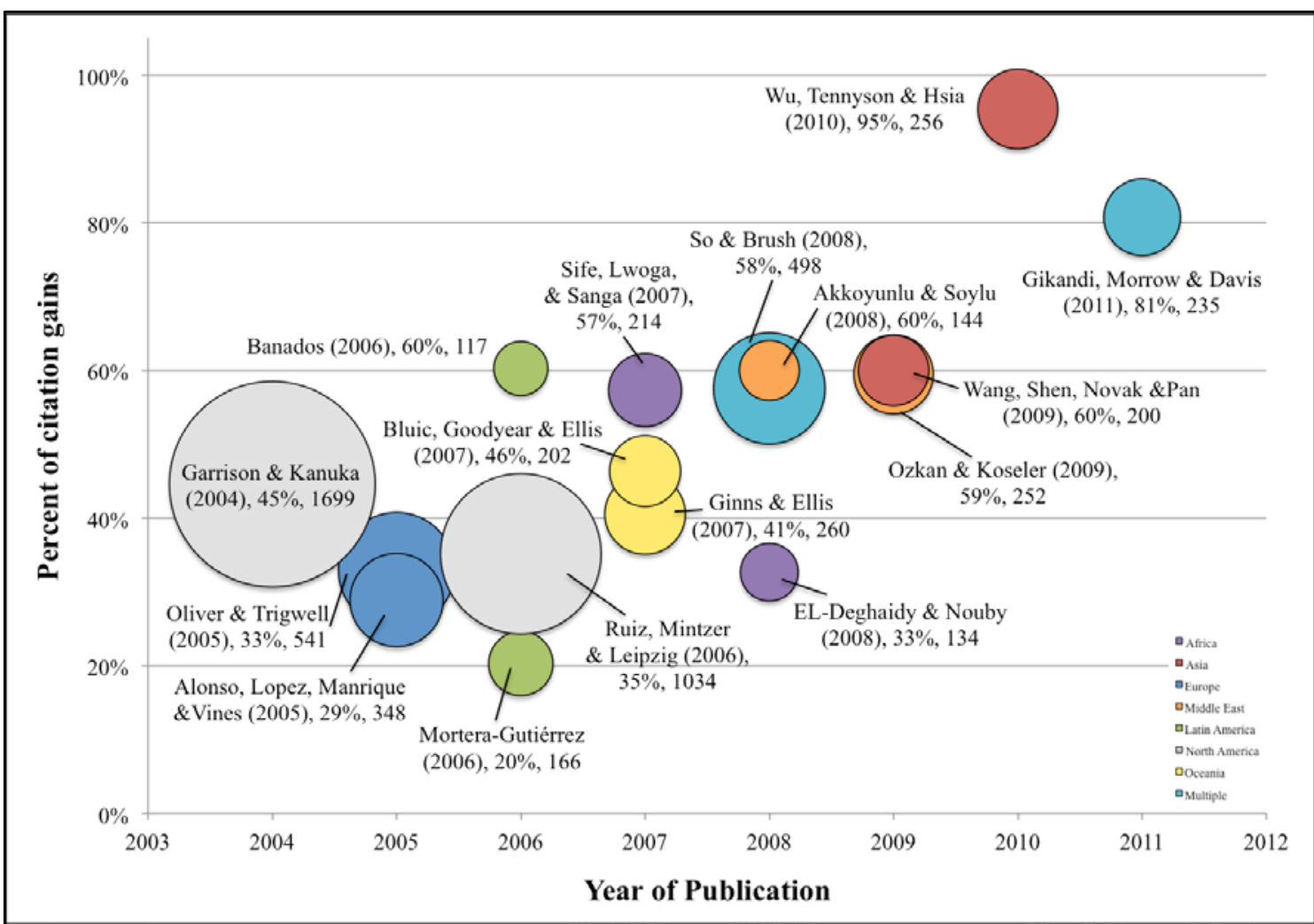

Figure 2. Most cited blended learning articles for each region listed by year of publication (x-axis) and gains in citations between our 2013 and 2016 counts (y-axis). The size of each bubble denotes the total number of citations. Colour and/or pattern reflect the region each article is affiliated with. Author(s), year of publication, total citations and citation gains are included in each label.

North America leads the other regions both in total citations and average citations per year. The most cited European articles emerged concurrently with the most cited articles from North America (2004-2006), but had fewer citations. Our most cited North American article overall (Garrison \& Kanuka, 2004) discussed the potential of BL, while the highest cited article from Europe (Oliver \& Trigwell, 2005), focused on difficulties with defining and therefore pursuing BL. Both of these highly cited articles, which discussed major BL issues, were published very early in the development of BL. A reasonable conclusion is that they have both been used by hundreds researchers in the developing field to establish context for their inquiry.

Articles associated with Oceania, Asia, and articles connected to multiple regions dominate the middle category, was led by So and Brush (2008). This practice-based article describes a post-secondary course with a combination of inferential statistics and qualitative analysis, making it both relevant and credible to other authors. This article is relatively recent but highly cited, following a pattern we noted throughout the world. Most of the articles from the less cited regions appeared even more recently. All those from the Middle East, for instance, were published after 2007. Three articles, two from Africa and one from Latin America were published as recently as 2012. Since articles from these regions are less frequently cited overall, newer articles with less time to garner citations top the list because there are fewer older articles to compete with.

While updating citation counts, we noticed startling jumps in citations from a few articles. The average gain in citations from 2013-2014 was 39.5\%, which suggests that interest in BL worldwide is currently increasing-if not exponentially, at least very rapidly. For articles that began with fewer citations, a larger percentage of growth was not surprising, but some articles that began with a high citation count also grew dramatically. Gikandi, Morrow and Davis (2011) increased 73.1\% from 35 citations in 2013 to 130 citations in 2014 and then 
80.8\% (130 cites-235 cites) from 2014 to 2016. Garrison and Kanuka (2004), the mostly highly cited article in 2013, increased by 53.7\% between 2013-2014 and another $44.6 \%$ between 2014-2016 to remain the most cited article in our final counts.

Figure 3 shows a wide spread of contributions from 34 countries, which suggests BL implementation in many locales. Regions generally contributed articles from several countries. Even Latin America, which had fewer included papers than other regions, was represented by seven countries. Europe was also quite varied, including publications from seven countries. Some regions were clearly dominated by a single country like Africa (South Africa), the Middle East (Turkey), and Oceania (Australia). This is likely affected by the size of the populations and proportion of English speakers in these nations, and their relative development when compared to other nations in their respective regions.

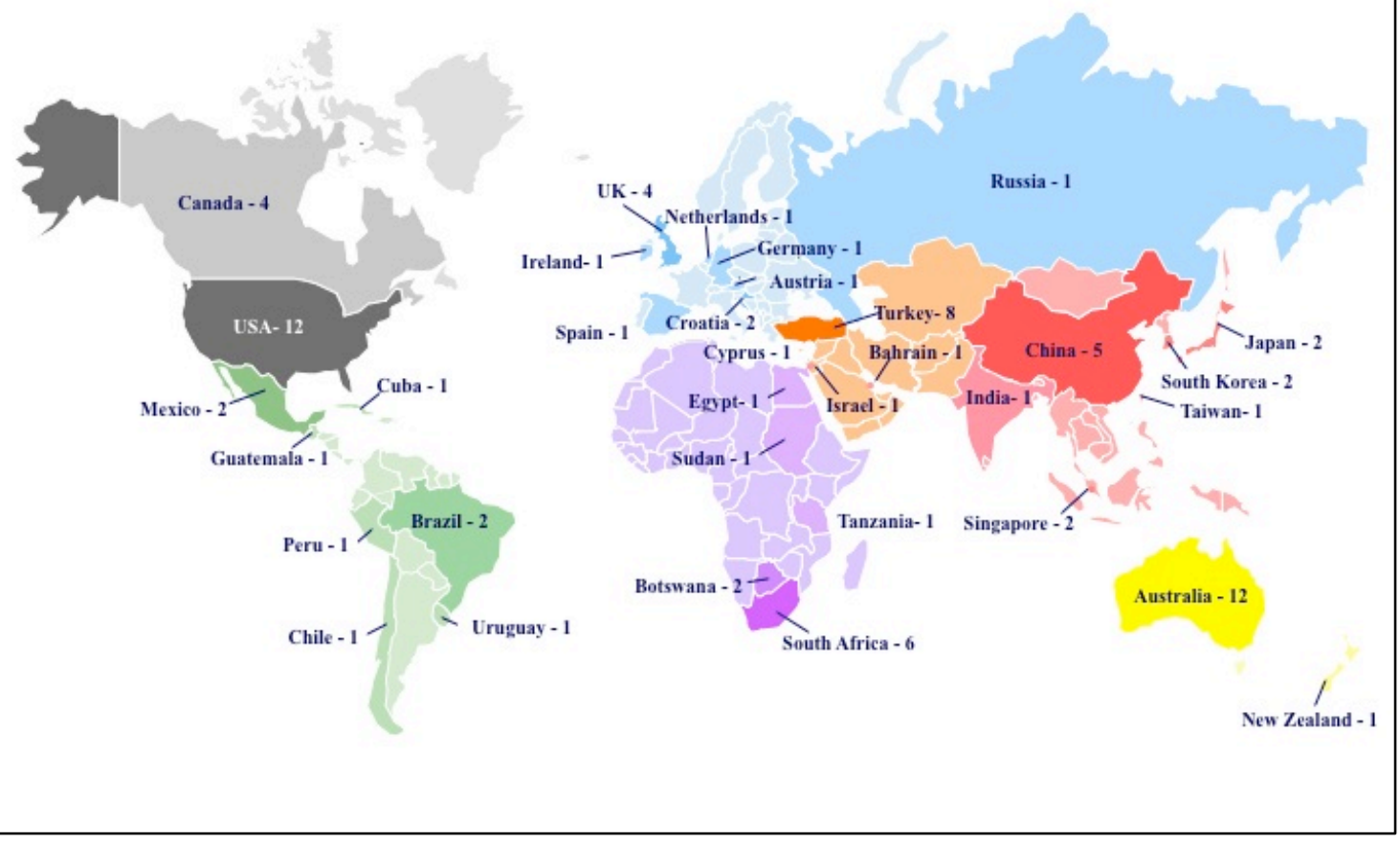

Figure 3. Countries the top articles originate from or are affiliated with. Some articles are affiliated with multiple countries. Where the article lists those countries they are included.

\section{Most cited researchers and collaboration}

An author's popularity and prestige are potentially linked to numerous factors, including citations, quality of citations, organisational affiliation, and honours (Ding \& Cronin, 2011). Analysing authors in the field of humanities, Evans (2005) argued "prestigious authors influence debates not only by writing more and higher quality texts, but also by other authors building upon their work in order to legitimate their texts" (p. 126). We based our determination of the most prestigious authors in the field of BL in each region and worldwide on the number of articles and citations. But only 11 authors had published more than one article in our most cited lists.

Several of the most cited authors have formed a cluster. For instance Ellis (6 articles), Goodyear (5 articles), O'Hara (2 articles), and Prosser (3 articles) each coauthors one or more of the articles in our most cited list with 
another member of the group. They took turns assuming the responsibility of first authorship. This cluster is generally intra-regional, based in Oceania, but maintains ties when members base themselves in Europe or Asia as well. Members of larger research teams may be more likely to connect more with international peers and publish in international journals (Horta \& Lacy, 2011) Researches in Columbia found that international coauthoring could improve productivity and focus research on country-specific issues (Ordóñez-Matamoros, Cozzens, \& Garcia, 2010), which seems to be occurring within this group.

Further collaboration patterns emerge from the multiple region category. Two describe ties between Africa and the Europe or Oceania. One of these involves outside researchers studying Africa (Unwin, 2004), while the other presents a traditional partnership including researchers at universities in different regions (Morrow \& Davis, 2011). Two articles represent a single project operating across several countries (Oh \& Park, 2009; So \& Bonk, 2010). Other inter-regional collaboration appears among most cited articles centered outside North America but collaborating with a North American scholar or site. Of these, two are affiliated with Asia (Lynch \& Dembo, 2004; So \& Brush, 2008) and one with the Middle East (Akyol \& Garrison, 2011). Two of the most cited articles represented collaboration between Asia and Oceania, two regions in close proximity (Ellis, Goodyear, Calvo, \& Prosser, 2008; Pearson \& Trinidad, 2005). In the most cited articles we found no collaboration between North America and Europe-close neighbours linguistically and culturally. While we found light patterns, we observed limited collaboration and/or international interest throughout the BL community.

\section{Regional citations}

Though we compared the 10 most cited articles from each region, we found a large disparity among their total citations (Figure 4). North America exceeds the others, with twice as many citations than the next highest, Europe. Oceania (3rd) and Asia (4th) each garnered about half as many as Europe. We expected diversity but were surprised to find such a stark contrast.

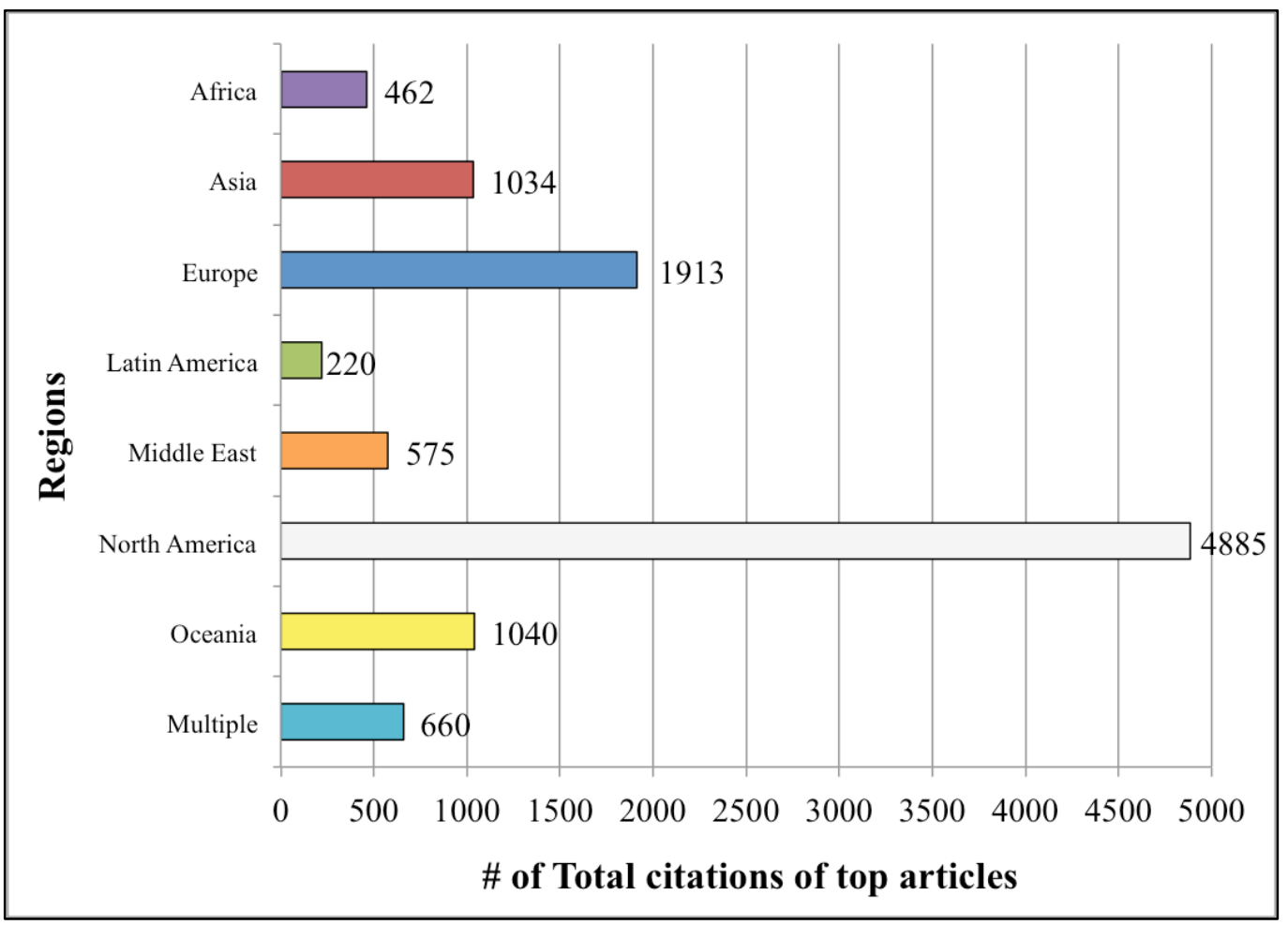

Figure 4. Total citations of top articles by region 


\section{Citation Connections}

Effective connections would be recognised by other regions, which would look to them for insights. Based on our most cited articles, regions have either a strong in-degree, being highly cited, like North America, or a strong out-degree, heavily citing other regions, like the Middle East (Figure 5). The regions with the most balance, Oceania and articles from multiple regions, have a split of about one-third in to two-thirds out.

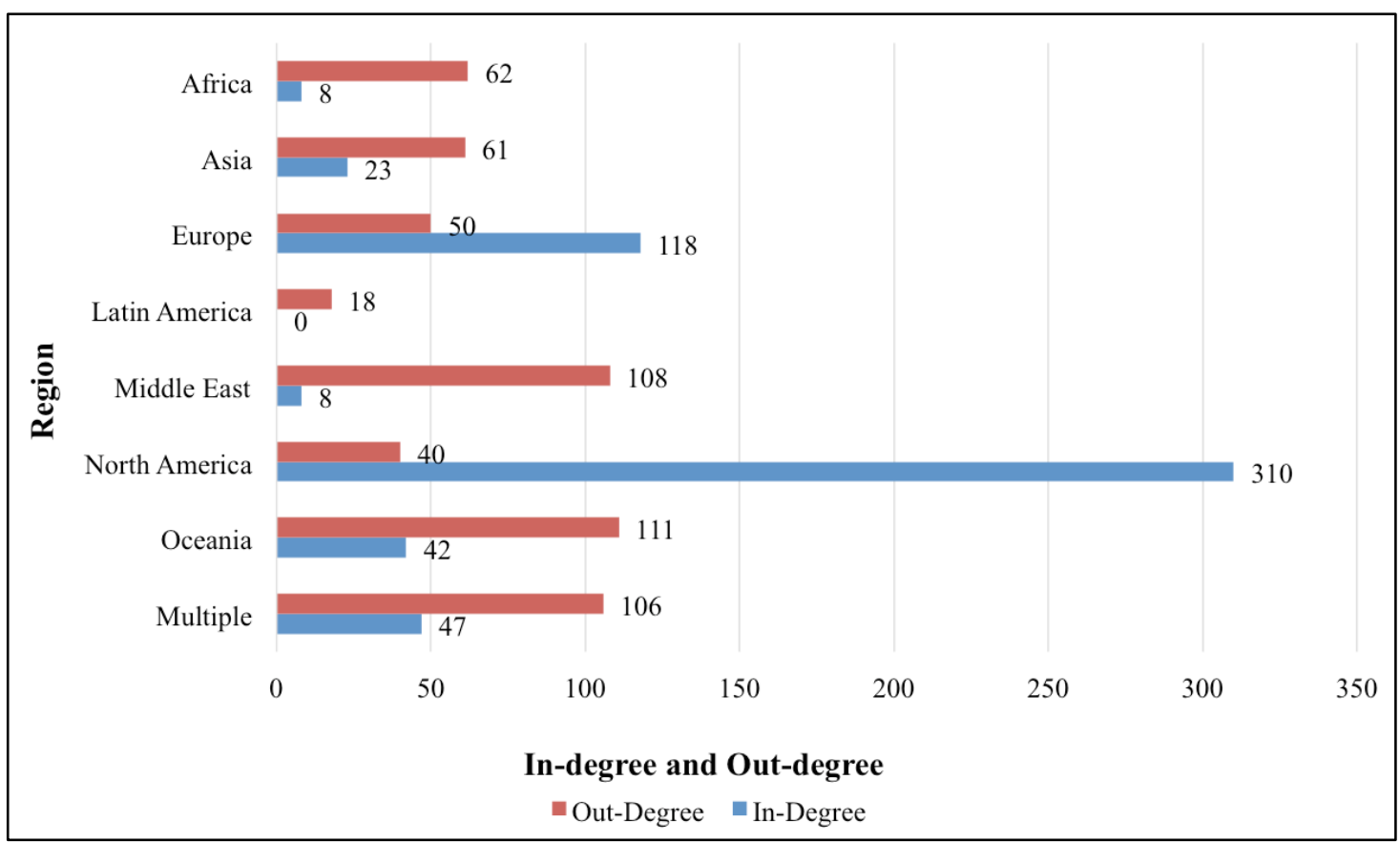

Figure 5. Total in-degree and out-degree of the top articles in each region

North American articles received the most citations by articles from other regions. The regions doing the citing were varied (Figure 6). The Middle East cited North American articles 78 times, almost twice as much as Oceania (44 times) or Europe (28 times) despite linguistic, cultural, and geographic bonds between Oceania, Europe, and North America. In contrast, Oceania and Europe have the strong bond that would be expected from this sort of closeness (30 connections from Oceania to Europe). Each region is connected to North America, and Europe and the multiple region category are connected to all the regions except Latin America, while connections are sparser among other regions. 


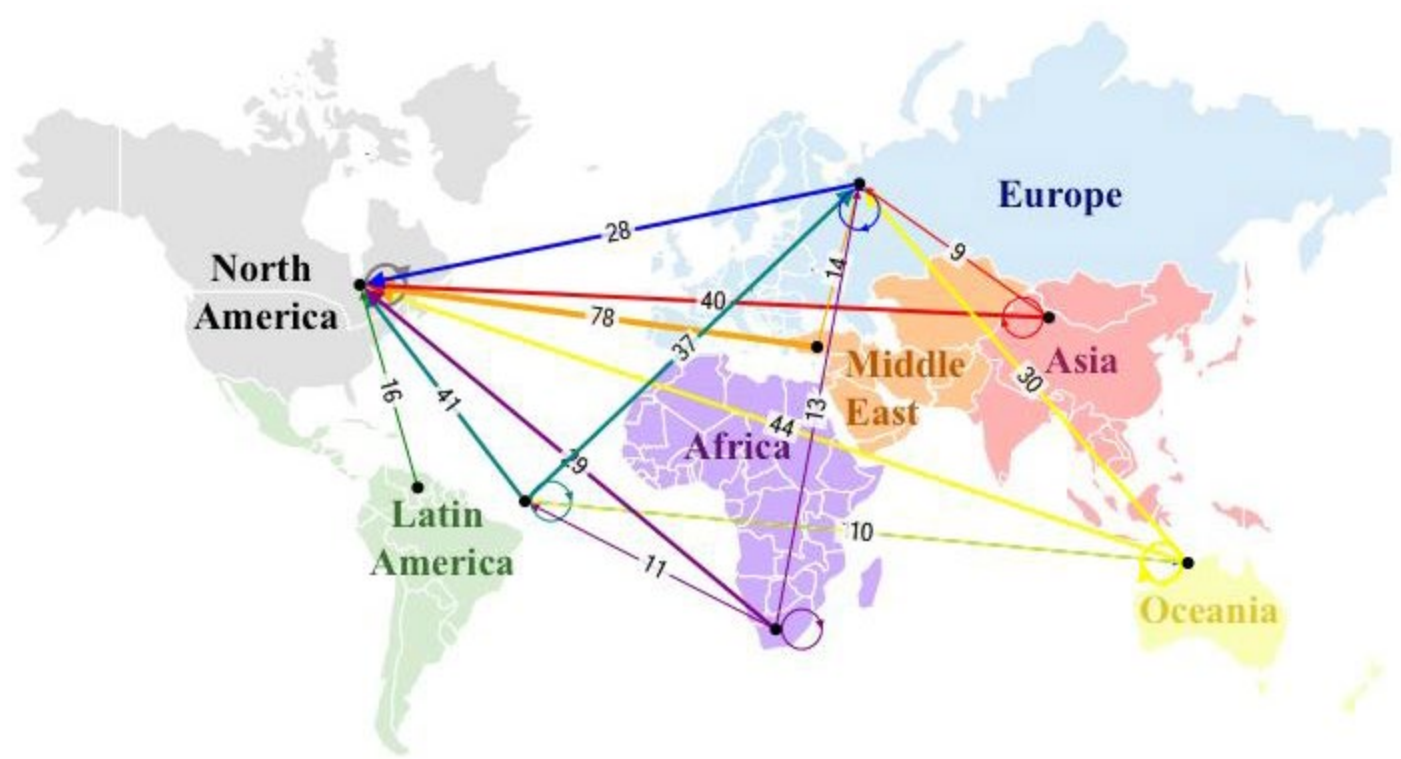

Figure 6. Social network analysis of citation between regions of the world. Each node represents a region and each edge represents the number of articles affiliated with one region citing articles affiliated with another region. Arrows indicate directionality and line thickness indicates the strength of the connection. Some regions are not connected in this figure because they did not cite one another five times or more. Only articles in the top most cited list and/or featured in the references of two or more top articles are included $(N=556)$. Created using NodeXL.

Of the over 2000 unique articles cited by our most cited articles, only the 19 included in Figure 7 were cited more than five times. Only five of those were among our original most cited articles and each of these articles was among the most cited articles overall compiled by Halverson et al. (2012). These articles discuss theoretical or design topics. They were published early in the development of BL, three in 2003, and the others in 2004 and 2005. It is reasonable that promising researchers would look to early theoretical articles to ground their explorations. 


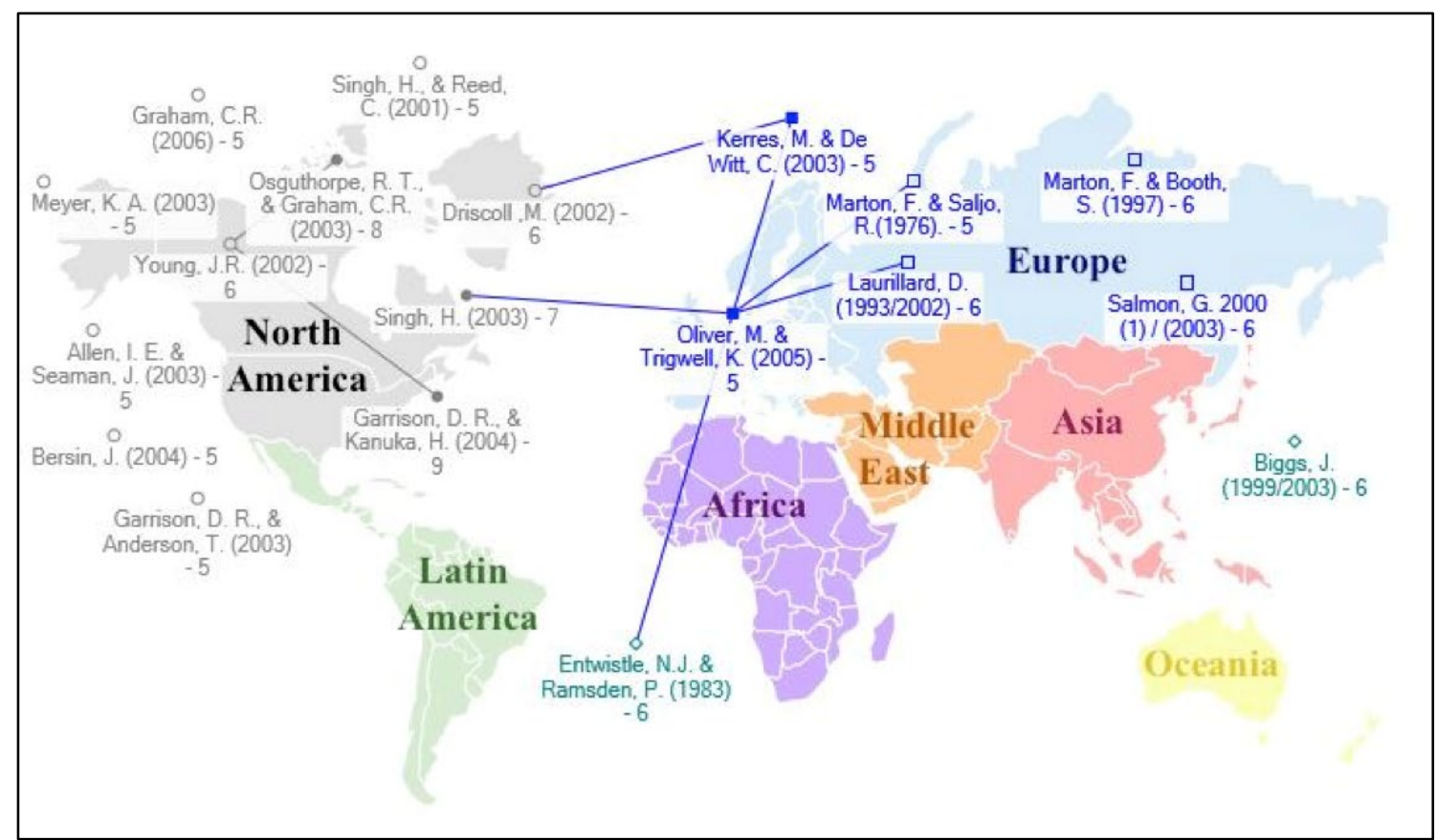

Figure 7. Social network analysis of citation between top publications with the highest in-degrees. Publications with an in-degree of five or higher were included $(N=19)$. Each node represents an article and each edge represents a citation. Arrows indicate directionality. Each node is labeled with author(s), year and in-degree. Created using NodeXL.

Our most cited articles cited Garrison and Kanuka (2004), the article with the highest in-degree, nine times (it was referenced in $11.8 \%$ of our most cited articles). It discusses the transformative potential of BL, specifically in the context of post-secondary education. Overall this article is obviously foundational (Halverson et al, 2012), but its influence has not spread as widely to the international BL community. The article citing the most other included articles, therefore likely one of the most connected to the field, is Oliver and Trigwell (2005), which cites five of the articles with the highest in-degree. This article, a position paper on the difficulties of defining blended learning, drew heavily on important articles from the community due to its topics. While some articles are more influential than others within the worldwide BL field, clearly the international community has yet to agree on foundational articles.

\section{Publication patterns}

Our most cited 76 articles were published in 41 unique journals. Of those journals, eleven contained $60.5 \%$ of most cited publications (Figure 8). These journals are regionally diverse, and all but two have published most cited articles affiliated with two or more regions. The British Journal of Educational Technology, which published the most cited articles (8), features articles from five regions and focuses more on publications outside of its own region (6) than within (2). The other third of our most cited articles were published by 29 unique journals. While these journals may focus less on international BL, they reflect a wide interest in the topic within and without the field of education. 


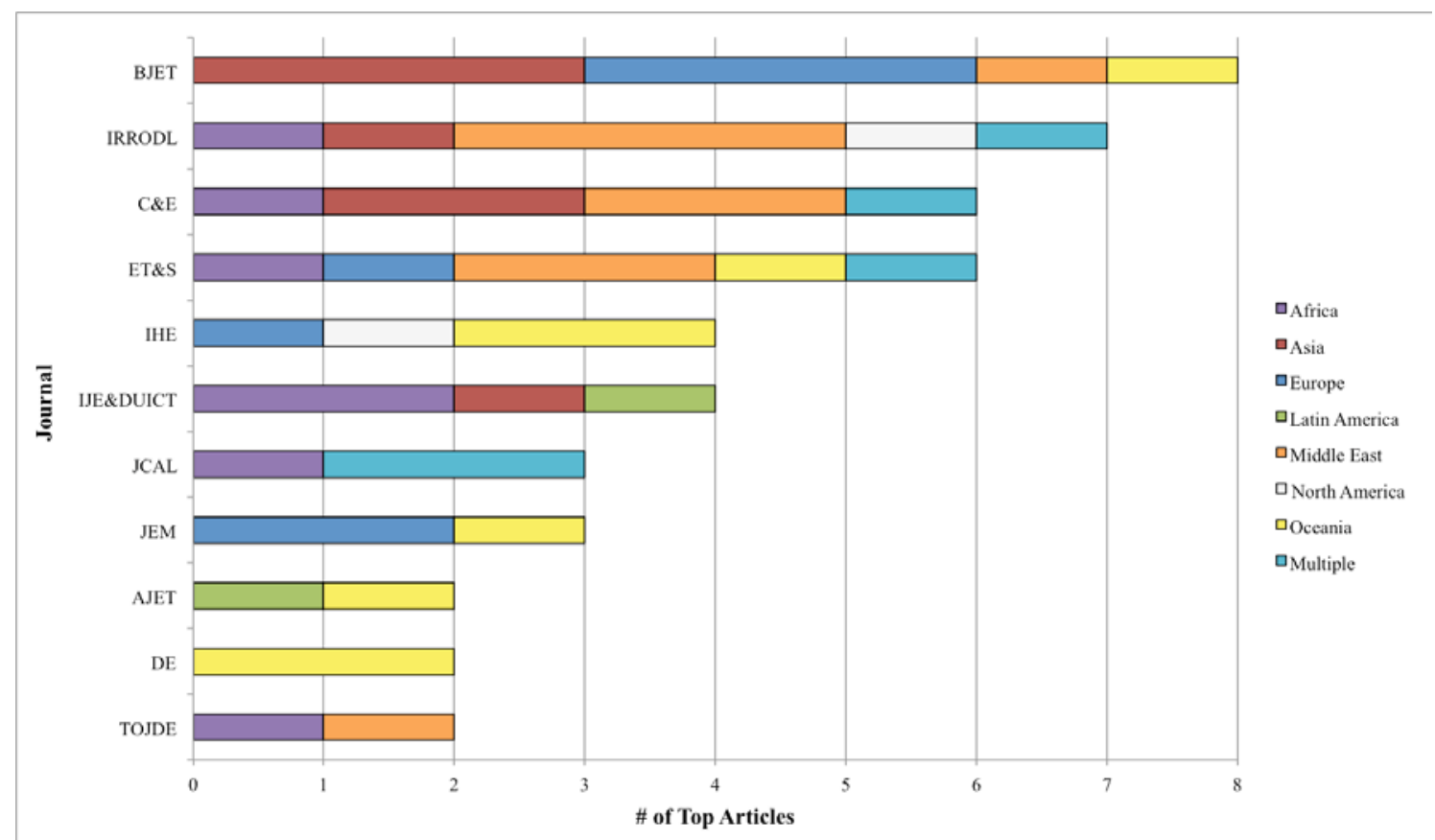

Figure 8. Journals (y-axis) that published two or more top articles (x-axis). Regions that each of the articles are affiliated with are denoted by colors and/or patterns.

While there are clearly top BL journals around the world, there is also a large variety of venues for BL articles. These top journals in each region also share six journals in common with the top journals for BL worldwide (Halverson et al, 2012). Top BL journals are open to publishing research from many regions, which allows the entire community greater access to the best work worldwide. There also seems to be some agreement among $\mathrm{BL}$ authors about the most prominent publication venues based on the high percentage of top-cited articles that are published in a select group of journals, which could help the community become more cohesive.

\section{Conclusions}

We categorise this project as explore research that can create a foundation for future explain and design research; specifically the goal of this study was to "define and categorize" (Graham, Henrie \& Gibbons, 2014, p. 16) the most cited BL publications worldwide. We aimed to explore where the most impactful conversations about BL worldwide are occurring and how, if at all, are they connected to one another in terms of citations and publications. We focused on the most frequently cited articles, and comparing them based on their regions of origin and publication venues. We have produced a look at theses issues and the most impactful BL conversations worldwide to build upon.

Overall we found a large disparity in citation patterns of BL research around the world. We expected to find divergence between regions, because of the disproportion of regional origins in Halverson et al. (2012), but discovered a gap that was greater than expected. This lack of connection could be a result of differences between regions that render collaboration inefficient. More research should be done on the methods, contexts, and research questions of important research worldwide to address this issue. Another explanation, however, is that there is much untapped potential for BL researchers around the world to benefit from each other's work. We see in our multiple region category instances of successful collaboration and connection among distant and unique regions that could be echoed elsewhere.

While the field is not yet where we hoped, we see much potential for global collaboration and cooperative growth. The bias towards North America in our findings is likely influenced by our limitation to English-only 
articles. We expect there are thriving BL conversations in other languages we have not been able to tap into. It is also possible that different regions use different terms for BL, making it more difficult for researchers to find one another. We are encouraged by the highly ranked articles from less cited regions that have been published in recent years and by the growth in citations over time across all regions and look forward to further development in these arenas. These findings suggest to us that while BL research from North America is currently cited most widely worldwide, BL is also actively growing elsewhere. Our findings are unfortunately limited by our language abilities and the offerings in the databases we searched, but we submit that a look even at the most cited English articles can give us a glimpse of the BL field worldwide, especially because English is the most common language in academic publishing (Belcher, 2007).

We believe there are several ways that international BL connections can enrich and strengthen the global community. For example, it contributes experience with educating in contexts that may be common in one region but infrequent and less researched in another. Research may also address the challenges of blending in developing locations and implementing inventive solutions with new technology that is applicable across regions that could be more strongly connected. International researchers may also have experience with educating students with varied cultural and linguistic backgrounds. The yet independent nature of most BL initiatives might have also rendered them laboratories of innovation and creative ideas that we can all learn from.

Future research should examine the themes of most cited articles to determine the level of cohesion or diversity among the topics and methods in BL research worldwide. It should also search for themes that are common areas of interest across regions. More in-depth research should also be done on each region and on BL research published in other languages. Latin America is a region of special interest because we were able to find so few BL articles in English there, and we expect there is much more available in other languages. Other research might focus on BL practitioners who are not publishing in research journals, especially those focused on the primary or corporate sectors. We look forward to the future of BL as we all continue to learn more about advances globally and work together to improve the field as a whole.

\section{References}

Akkoyunlu, B., \& Soylu, M. Y. (2008). A study of student's perceptions in a blended learning environment based on different learning styles. Educational Technology \& Society, 11(1), 183-193. Retrieved from http://www.jstor.org/stable/jeductechsoci.11.1.183

Akyol, Z., \& Garrison, D. R. (2011). Understanding cognitive presence in an online and blended community of inquiry: Assessing outcomes and processes for deep approaches to learning. British Journal of Educational Technology, 42(2), 233-250. http://dx.doi.org/10.1111/j.1467-8535.2009.01029.x

Alammary, A., Sheard, J., \& Carbone, A. (2014). Blended learning in higher education: Three different design approaches. Australasian Journal of Educational Technology, 30(4), 440-454. Retrieved from http://ajet.org.au/index.php/AJET/article/viewFile/693/1061

Alonso, F., López, G., Manrique, D., \& Viñes, J. M. (2005). An instructional model for web-based e-learning education with a blended learning process approach. British Journal of Educational Technology, 36(2), 217-235. http://dx.doi.org/10.1111/j.1467-8535.2005.00454.x

Banados, E., \& Ba, E. (2006). A blended-learning pedagogical model for teaching and learning EFL successfully through an online interactive multimedia environment. Calico Journal, 23(3), 533-550. Retrieved from http://www.jstor.org/stable/24156354

Barbour, M. K. (2011). The promise and the reality: Exploring virtual schooling in rural jurisdictions. Education in Rural Australia, 21(1), 1-20. Retrieved from http://search.informit.com.au/documentSummary;dn=183958620656095;res=IELAPA

Belcher, D. D. (2007). Seeking acceptance in an English-only research world. Journal of Second Language Writing, 16(1), 1-22. http://dx.doi.org/10.1016/j.jslw.2006.12.001

Benson, R., \& Samarawickrema, G. (2009). Addressing the context of e-learning: Using transactional distance theory to inform design. Distance Education, 30(1), 5-21. http://dx.doi.org/10.1080/01587910902845972 
Berger, H., Eylon, B.-S., \& Bagno, E. (2008). Professional development of physics teachers in an evidencebased blended learning program. Journal of Science Education and Technology, 17(4), 399-409. http://dx.doi.org/10.1007/s10956-008-9109-3

Bernard, R. M., Abrami, P. C., Borokhovski, E., Wade, C. a., Tamim, R. M., Surkes, M. A., \& Bethel, E. C. (2009). A meta-analysis of three types of interaction treatments in distance education. Review of Educational Research, 79(3), 1243-1289. http://dx.doi.org/10.3102/0034654309333844

Bernard, R. M., Borokhovski, E., Schmid, R. F., Tamim, R. M., \& Abrami, P. C. (2014). A meta-analysis of blended learning and technology use in higher education: from the general to the applied. Journal of Computing in Higher Education, 26(1), 87-122. http://dx.doi.org/10.1007/s12528-013-9077-3

Bhattacharya, I., \& Sharma, K. (2007). India in the knowledge economy - an electronic paradigm. International Journal of Educational Management, 21(6), 543-568. http://dx.doi.org/10.1108/09513540710780055

Bliuc, A.-M., Goodyear, P., \& Ellis, R. A. (2007). Research focus and methodological choices in studies into students' experiences of blended learning in higher education. The Internet and Higher Education, 10(4), 231-244. http://dx.doi.org/10.1016/j.iheduc.2007.08.001

Boitshwarelo, B. (2009). Exploring blended learning for science teacher professional development in an African context. International Review of Research in Open and Distance Learning, 10(4), 1-19. Retrieved from http://www.irrodl.org/index.php/irrodl/article/viewArticle/687

Bonk, C. J., \& Graham, C. R. (2006). The handbook of blended learning: Global perspectives, local designs [Google Books version]. Retrieved from https://books.google.com/books?hl=en\&lr=\&id=2u2TxK06PwUC\&oi=fnd\&pg=PT14\&dq=The+handbo ok+of+blended+learning:+Global+perspectives, +local+designs\&ots=a0FSD95Hcm\&sig=2rUCw2Uqx6cfDGJLeAD7yZC4c\#v=onepage\&q=The\%20handbook\%20of\%20blended\%20learning\%3A\%20Global\%20perspective s\%2C\%20local\%20designs\&f=false

Bonk, C. J., Kim, K.-J., \& Zeng, T. (2006). Future directions of blended learning in higher education and workplace learning settings. In C. J. Bonk, \& C. R. Graham (Eds.), The handbook of blended learning: Global perspectives, local designs (pp. 550-567). San Francisco, CA: Pfeiffer Publishing.

Bourne, J., Harris, D., \& Mayadas, F. (2005). Online engineering education: Learning anywhere, anytime. Journal of Engineering Education, (January), 131-146. http://dx.doi.org/10.1002/j.21689830.2005.tb00834.x

Boyle, T., Bradley, C., Chalk, P., Jones, R., \& Pickard, P. (2003). Using blended learning to improve student success rates in learning to program. Journal of Educational Media, 28(2), 165-178. http://dx.doi.org/10.1080/1358165032000153160

Bozalek, V., \& Biersteker, L. (2010). Exploring Power and Privilege Using Participatory Learning and Action Techniques. Social Work Education, 29(5), 551-572. http://dx.doi.org/10.1080/02615470903193785

Bozalek, V., Rohleder, P., Carolissen, R., Leibowitz, B., Nicholls, L., \& Swartz, L. (2008). Students learning across differences in a multi-disciplinary virtual learning community. South African Journal of Higher Education, 21(7), 812-826. http://dx.doi.org/10.4314/sajhe.v21i7.25744

Breeze, R. (2015). Citing outside the community? An investigation of the language of bibliography in top journals. In Alastrué, R. P. \& Pérez-Llantada, C. (Eds.), English as a scientific and research language: Debates and discourses English in Europe, (pp. 37-58). Berlin: Walter de Gruyter.

Brown, B. W., \& Liedholm, C. E. (2002). Can web courses replace the classroom in principles of microeconomics? The American Economic Review, 92(2), 444-448. http://dx.doi.org/10.1257/000282802320191778

Chandra, V., \& Lloyd, M. (2008). The methodological nettle: ICT and student achievement. British Journal of Educational Technology, 39(6), 1087-1098. http://dx.doi.org/10.1111/j.1467-8535.2007.00790.x

Concannon, F., Flynn, A., \& Campbell, M. (2005). What campus-based student think about the quality and he benefits of e-learning. British Journal of Educational Technology, 36(3), 501-512. http://dx.doi.org/10.1111/j.1467-8535.2005.00482.x

Cox, G., Carr, T., \& Hall, M. (2004). Evaluating the use of synchronous communication in two blended courses. Journal of Computer Assisted Learning, 20, 183-193. http://dx.doi.org/10.1111/j.13652729.2004.00084.x 
Cronjé, J. C. (2011). Using Hofstede's cultural dimensions to interpret cross-cultural blended teaching and learning. Computers \& Education, 56(3), 596-603. http://dx.doi.org/10.1016/j.compedu.2010.09.021

Curry, M. J., \& Lillis, T. (2004). Multilingual scholars and the imperative to publish in English: Negotiating interests, demands, and rewards. TESOL Quarterly, 38(4), 663. http://dx.doi.org/10.2307/3588284

Dantas, A. M., \& Kemm, R. E. (2008). A blended approach to active learning in a physiology laboratorybased subject facilitated by an e-learning component. Advances in Physiology Education, 32(1), 65-75. http://dx.doi.org/10.1152/advan.00006.2007

de Espíndola, M. B., El-Bacha, T., Giannella, T. R., Struchiner, M., da Silva, W. S., \& Da Poian, A. T. (2010). Teaching energy metabolism using scientific articles: Implementation of a virtual learning environment for medical students. Biochemistry and Molecular Biology Education: A Bimonthly Publication of the International Union of Biochemistry and Molecular Biology, 38(2), 97-103. http://dx.doi.org/10.1002/bmb.20386

DeGeorge-Walker, L., \& Keeffe, M. (2010). Self-determined blended learning: a case study of blended learning design. Higher Education Research \& Development, 29(1), 1-13. http://dx.doi.org/10.1080/07294360903277380

Delialioglu, O., \& Yildirim, Z. (2007). Students' perceptions on effective dimensions of interactive learning in a blended learning environment. Educational Technology \& Society, 10, 133-146. Retrieved from http://www.jstor.org/stable/jeductechsoci.10.2.133

Derntl, M., \& Motschnig-Pitrik, R. (2005). The role of structure, patterns, and people in blended learning. The Internet and Higher Education, 8(2), 111-130. http://dx.doi.org/10.1016/j.iheduc.2005.03.002

Ding, Y., \& Cronin, B. (2011). Popular and/or prestigious? Measures of scholarly esteem. Information Processing \& Management, 47(1), 80-96. http://dx.doi.org/10.1016/j.ipm.2010.01.002

Drysdale, J. S., Graham, C. R., Spring, K. J., \& Halverson, L. R. (2013). Analysis of research trends in dissertations and theses studying blended learning. Internet and Higher Education, 17(1), 90-100. http://dx.doi.org/10.1016/j/iheduc.2012.11.003

EL-Deghaidy, H., \& Nouby, A. (2008). Effectiveness of a blended e-learning cooperative approach in an Egyptian teacher education programme. Computers \& Education, 51(3), 988-1006. http://dx.doi.org/10.1016/j.compedu.2007.10.001

Ellis, R. A., Goodyear, P., Calvo, R. A., \& Prosser, M. (2008). Engineering students' conceptions of and approaches to learning through discussions in face-to-face and online contexts. Learning and Instruction, 18(3), 267-282. http://dx.doi.org/10.1016/j.learninstruc.2007.06.001

Ellis, R. A., Goodyear, P., O’Hara, A., \& Prosser, M. (2007). The university student experience of face-toface and online discussions: Coherence, reflection and meaning. Alt-J: Research in Learning Technology, 15(1), 83-97. http://dx.doi.org/10.1080/09687760601130057

Ellis, R. A., Goodyear, P., Prosser, M., \& O’Hara, A. (2006). How and what university students learn through online and face- to- face discussion: Conceptions, intentions and approaches. Journal of Computer Assisted Learning, 22(4), 244-256. http://dx.doi.org/10.1111/j.1365-2729.2006.00173.x

ERIC. (2014). An indispensible resource for educational literature. Retrieved from https://www.ebscohost.com/us-high-schools/eric.

Evans, J. H. (2005). Stratification in knowledge production: Author prestige and the influence of an American academic debate. Poetics, 33(2), 111-133. http://dx.doi.org/10.1016/j.poetic.2005.02.002

Garrison, D. R., \& Kanuka, H. (2004). Blended learning: Uncovering its transformative potential in higher education. The Internet and Higher Education, 7(2), 95-105. http://dx.doi.org/10.1016/j.iheduc.2004.02.001

Garrote, R., Pettersson, T., \& Christie, M. (2011). LiveUSB Mediated Education: A method to facilitate computer supported education. Australasian Journal of Educational Technology, 27(4), 619-632. Retrieved from http://www.diva-portal.org/smash/record.jsf?pid=diva2\%3A871242\&dswid=3030

Gikandi, J. W., Morrow, D., \& Davis, N. E. (2011). Online formative assessment in higher education: A review of the literature. Computers \& Education, 57(4), 2333-2351. http://dx.doi.org/10.1016/j.compedu.2011.06.004

Ginns, P., \& Ellis, R. (2007). Quality in blended learning: Exploring the relationships between on-line and face-to-face teaching and learning. The Internet and Higher Education, 10(1), 53-64.

http://dx.doi.org/10.1016/j.iheduc.2006.10.003 
Goodyear, P., \& Ellis, R. A. (2008). University students' approaches to learning: rethinking the place of technology. Distance Education, 29(2), 141-152. http://dx.doi.org/10.1080/01587910802154947

Graham, C. R. (2013). Emerging practice and research in blended learning. Handbook of distance education, 3 [Google Books version]. Retrieved from

https://books.google.com/books?id=FPpDkFVYetQC\&printsec=frontcover\&dq=Handbook+of + distance +education\&hl=en\&sa=X\&ved=0ahUKEwjcsICG4qjOAhVJ72MKHZTzDhoQ6AEIKjAA\#v=onepage\& q=Handbook\%20of\%20distance\%20education\&f=false

Graham, C. R., Henrie, C. R., \& Gibbons, A. S. (2014). Developing models and theory for blended learning research. In A. G. Picciano, C. D. Dziuban, \& C. R. Graham (Eds.), Blended learning: Research perspectives (2nd ed., pp. 13-33). New York, NY: Routledge.

Gülbahar, Y., \& Madran, R. O. (2009). Communication and collaboration, satisfaction, equity, and autonomy in blended learning environments: A case from Turkey. International Review of Research in Open and Distance Learning, 10(2), 1-22. Retrieved from http://eric.ed.gov/?id=EJ844026

Hall, H., \& Davison, B. (2007). Social software as support in hybrid learning environments: The value of the blog as a tool for reflective learning and peer support. Library \& Information Science Research, 29(2), 163-187. http://dx.doi.org/10.1016/j.lisr.2007.04.007

Halverson, L. R., Graham, C. R., Spring, K. J., \& Drysdale, J. S. (2012). An analysis of high impact scholarship and publication trends in blended learning. Distance Education, 33(3), 381-413. http://dx.doi.org/10.1080/01587919.2012.723166

Hoic-Bozic, N., Mornar, V., \& Boticki, I. (2009). A blended learning approach to course design and implementation. IEEE Transactions on Education, 52(1), 19-30. http://dx.doi.org/10.1109/TE.2007.914945

Holley, D., \& Oliver, M. (2010). Student engagement and blended learning: Portraits of risk. Computers \& Education, 54(3), 693-700. http://dx.doi.org/10.1016/j.compedu.2009.08.035

Horta, H., \& Lacy, T. A. (2011). Science and public policy: How does size matter for science? Exploring the effects research unit size on academics' scientific productivity and information exchange behaviors. Science and Public Policy, 38(6), 449-460. http://dx.doi.org/10.3152/030234211X12960315267813

Indices \& Data: Human Development Index. (2011). United Nations Development Program. Retrieved from http://hdr.undp.org/en/statistics/hdi/

Jamlan, M. (2004). Faculty opinions towards introducing e-learning at the University of Bahrain. International Review of Research in Open and Distance Learning, 5(2), 1-14. Retrieved from http://www.irrodl.org/index.php/irrodl/article/viewArticle/185

Keppell, M., \& Carless, D. (2006). Learning oriented assessment: A technology based case study. Assessment in Education: Principles, Policy \& Practice, 13(2), 179-191. http://dx.doi.org/10.1080/09695940600703944

Kerres, M., \& De Witt, C. (2003). A didactical framework for the design of blended learning. Journal of Educational Media, 28(2), 101-113. http://dx.doi.org/10.1080/1358165032000165653

Khine, M. S., \& Lourdusamy, A. (2003). Blended learning approach in teacher education: combining face-toface instruction, multimedia viewing and online discussion. British Journal of Educational Technology, 34(5), 671-676. http://dx.doi.org/10.1046/j.0007-1013.2003.00360.x

Kilduff, M., \& Tsai, W. (2003). Social networks and organizations. London, UK: Sage.

Kim, K.-J., \& Bonk, C. J. (2006). The future of online teaching and learning in higher education: The survey says .... Educause Quarterly, 29(4), 22-30. Retrieved from http://er.educause.edu/articles/2006/1/thefuture-of-online-teaching-and-learning-in-higher-education-the-survey-says

Kırkgöz, Y. (2011). A blended learning study on implementing video recorded speaking tasks in task-based classroom instruction. The Turkish Online Journal of Educational Technology, 10(4), 1-13. Retrieved from http://search.proquest.com/openview/33b39b89bda6c53f232ae78095a835a2/1?pq-origsite=gscholar

Korkmaz, O., \& Karakus, U. (2009). The impact of blended learning model on student attitudes towards geography course and their critical thinking dispositions and levels. The Turkish Online Journal of Distance Education, 8(4), 51-63. Retrieved from http://search.proquest.com/openview/d404c19d8c25bd72768b640868b3ddd6/1?pq-origsite=gscholar

Lillis, T., \& Curry, M. J. (2010). Academic writing in a global context: The politics and practices of publishing in English. Abingdon, VA: Routledge. 
Llambi, L., Esteves, E., Martinex, E., Forster, T., Garcia, S., Miranda, N. ... Margolis, A. (2011). Teaching tobacco cessation skills to Uruguayan physicians using information and communication. Journal of Continuing Education in the Health Professions, 31(1), 43-48. http://dx.doi.org/10.1002/chp.20100

López-Pérez, M. V., Pérez-López, M. C., \& Rodríguez-Ariza, L. (2011). Blended learning in higher education: Students' perceptions and their relation to outcomes. Computers \& Education, 56(3), 818826. Retrieved from http://dx.doi.org/10.1016/j.compedu.2010.10.023

Lynch, R., \& Dembo, M. (2004). The relationship between self-regulation and online learning in a blended learning context. International Review of Research in Open and Distance Learning, 5(2), 1-16. Retrieved from http://www.irrodl.org/index.php/irrodl/article/viewArticle/189

Miyazoe, T., \& Anderson, T. (2010). Learning outcomes and students' perceptions of online writing: Simultaneous implementation of a forum, blog, and wiki in an EFL blended learning setting. System, 38(2), 185-199. http://dx.doi.org/10.1016/j.system.2010.03.006

Mortera-Gutiérrez, F. (2006). Faculty best practices using blended learning in e-learning and face-to-face instruction. International Journal on E-Learning, 5(3), 313-337. Retrieved from http://search.proquest.com/openview/6d492f079007137bca888a93b2c99075/1?pq-origsite=gscholar

Neumann, D. L., \& Hood, M. (2009). The effects of using a wiki on student engagement and learning of report writing skills in a university statistics course. Australasian Journal of Educational Technology, 25(3), 382-398. Retrieved from http://citeseerx.ist.psu.edu/viewdoc/download?doi=10.1.1.177.7627\&rep=rep1\&type=pdf

Ng'ambi, D., Lombe, A., \& Ng, D. (2012). Using podcasting to facilitate student learning: A constructivist perspective, 15 (4), 181-192. Retrieved from http://www.jstor.org/stable/jeductechsoci.15.4.181

Norberg, A., Dziuban, C. D., \& Moskal, P. D. (2011). A time-based blended learning model. On the Horizon, 19(3), 207-216. http://dx.doi.org/10.1108/10748121111163913

Ocak, M. A. (2011). Why are faculty members not teaching blended courses? Insights from faculty members. Computers \& Education, 56(3), 689-699. http://dx.doi.org/10.1016/j.compedu.2010.10.011

Oh, E., \& Park, S. (2009). How are universities involved in blended instruction? Educational Technology \& Society, 12(3), 327- 342. Retrieved from http://www.jstor.org/stable/jeductechsoci.12.3.327

Oliver, M., \& Trigwell, K. (2005). Can “blended learning” be redeemed? E-Learning, 2(1), 17-26. http://dx.doi.org/10.2304/elea.2005.2.1.2

Ordóñez-Matamoros, H. G., Cozzens, S. E., \& Garcia, M. (2010). International Co-Authorship and Research Team Performance in Columbia. Review of Policy Research, 27(4), 415-431. http://dx.doi.org/10.1111/j.1541-1338.2010.00449.x

Osguthorpe, R. T., \& Graham, C. R. (2003). Blended learning environments: Definitions and directions. Quarterly Review of Distance Education, 4(3), 227-234. Retrieved from http://eric.ed.gov/?id=EJ678078

O'Toole, J. M., \& Absalom, D. (2003). The impact of blended learning on student outcomes: Is there room on the horse for two? Journal of Educational Media, 28(2-3), 179-190. http://dx.doi.org/10.1080/1358165032000165680

Ozkan, S., \& Koseler, R. (2009). Multi-dimensional students' evaluation of e-learning systems in the higher education context: An empirical investigation. Computers \& Education, 53(4), 1285-1296. http://dx.doi.org/10.1016/j.compedu.2009.06.011

Pearson, J., \& Trinidad, S. (2005). OLES: An instrument for refining the design of e-learning environments. Journal of Computer Assisted Learning, 21(6), 396-404. http://dx.doi.org/10.1111/j.13652729.2005.00146.X

Peixoto, H. M., Peixoto, M. M., \& Alves, E. D. (2012). Learning strategies used by undergraduate and postgraduate students in hybrid courses in the area of health. Revista Latino-Americana de Enfermagem, 20(3), 551-8. Retrieved from http://www.ncbi.nlm.nih.gov/pubmed/22991118

Picciano, A. G., \& Seaman, J. (2007). K-12 online learning: A survey of U.S. school district administrators. Journal of Asynchronous Learning Networks, 11(3), 11-37. Retrieved from http://www.onlinelearningsurvey.com/reports/k-12-online-learning.pdf

Pineteh, E. A. (2012). Using virtual interactions to enhance the teaching of communication skills to information technology students. British Journal of Educational Technology, 43(1), 85-96. http://dx.doi.org/10.1111/j.1467-8535.2011.01193.x 
Precel, K., Eshet-Alkalai, Y., \& Alberton, Y. (2009). Pedagogical and design aspects of a blended learning course. International Review of Research in Open and Distance Learning, 10(2), 1-16. Retrieved from http://www.irrodl.org/index.php/irrodl/article/viewArticle/618

Prinsloo, P., \& VanRooyen, A. A. (2007). Exploring a blended learning approach to improving student success in the teaching of second year accounting. Meditari Accountancy Research, 15(1), 51-69. http://dx.doi.org/10.1108/10222529200700004

Rovai, A. P., \& Jordan, H. M. (2004). Blended learning and sense of community: A comparative analysis with traditional and fully online graduate courses. International Review of Research in Open and Distance Learning, 5(2), 1-13. Retrieved from http://www.irrodl.org/index.php/irrodl/article/viewArticle/192

Ruiz, J. G., Mintzer, M. J., \& Leipzig, R. M. (2006). The impact of e-learning in medical education. Academic Medicine : Journal of the Association of American Medical Colleges, 81(3), 207-12. Retrieved from http://www.ncbi.nlm.nih.gov/pubmed/16501260

Sanprasert, N. (2010). The application of a course management system to enhance autonomy in learning English as a foreign language. System, 38(1), 109-123. http://dx.doi.org/10.1016/j.system.2009.12.010

Shen, R., Wang, M., \& Pan, X. (2008). Increasing interactivity in blended classrooms through a cutting-edge mobile learning system. British Journal of Educational Technology, 39(6), 1073-1086. http://dx.doi.org/10.1111/j.1467-8535.2007.00778.x

Shih, R. (2011). Can Web 2.0 technology assist college students in learning English writing? Integrating Facebook and peer assessment with blended learning. Australasian Journal of Educational Techonology 27(5), 829-845. Retrieved from http://ajet.org.au/index.php/AJET/article/view/934

Sife, A. S., Lwoga, E. T., \& Sanga, C. (2007). New technologies for teaching and learning: Challenges for higher learning institutions in developing countries. International Journal of Education and Development Using Information and Communication Technology, 3(2), 57-67. Retrieved from http://ijedict.dec.uwi.edu/viewarticle.php?id=246/\&layout=html

Singh, H. (2003). Building effective blended learning programs. Educational Technology, 43(6), 51-54. Retrieved from http://www.asianvu.com/bk/UAQ/UAQ_WORKSHOP_PACKAGE/new/Appendix B blended-learning.pdf

So, H., \& Bonk, C. J. (2010). Examining the roles of blended learning approaches in computer-supported collaborative learning (CSCL) environments. A delphi study. Educational Technology \& Society, 13(3), 189-200. Retrieved from http://www.jstor.org/stable/jeductechsoci.13.3.189

So, H., \& Brush, T. (2008). Student perceptions of collaborative learning, social presence and satisfaction in a blended learning environment: Relationships and critical factors. Computers \& Education, 51(1), 318336. http://dx.doi.org/10.1016/j.compedu.2007.05.009

Sung, Y. H., Kwon, I. G., \& Ryu, E. (2008). Blended learning on medication administration for new nurses: Integration of e-learning and face-to-face instruction in the classroom. Nurse Education Today, 28(8), 943-52. http://dx.doi.org/10.1016/j.nedt.2008.05.007

Taradi, S. K., Taradi, M., Radic, K., \& Pokrajac, N. (2005). Blending problem-based learning with Web technology positively impacts student learning outcomes in acid-base physiology. Advances in Physiology Education, 29(March), 35-39. http://dx.doi.org/10.1152/advan.00026.2004

Tham, R., \& Tham, L. (2013). Challenges facing blended learning in higher education in Asia. International Journal on E-Learning, 12(2), 209-219. Retrieved from https://www.learntechlib.org/p/36166

Unwin, T. (2004). Towards a framework for the use of ICT in teacher training in Africa. Open Learning, 20(2), 1-26. http://dx.doi.org/10.1080/02680510500094124

Wang, M., Shen, R., Novak, D., \& Pan, X. (2009). The impact of mobile learning on students' learning behaviours and performance: Report from a large blended classroom. British Journal of Educational Technology, 40(4 (July)), 673-695. http://dx.doi.org/10.1111/j.1467-8535.2008.00846.x

Wu, J.-H., Tennyson, R. D., \& Hsia, T.-L. (2010). A study of student satisfaction in a blended e-learning system environment. Computers \& Education, 55(1), 155-164. http://dx.doi.org/10.1016/j.compedu.2009.12.012 
Corresponding author: Kristian J. Spring, kristian.spring@gmail.com

Australasian Journal of Educational Technology (c) 2017.

Please cite as: Spring, K. J., \& Graham, C. R.. (2017). Blended learning citation patterns and publication across seven worldwide regions. Australasian Journal of Educational Technology, 33(2), 24-50. https://doi.org/10.14742/ajet.2632 


\section{Appendix A}

Table A.1

10 most cited articles in Africa

\begin{tabular}{|c|c|c|c|c|c|c|}
\hline \# & $\begin{array}{l}\text { Total } \\
\text { cites }\end{array}$ & $\begin{array}{c}\text { Av } \\
\text { cites/yr }\end{array}$ & Authors & Title & Source & Country \\
\hline 1 & 214 & 23.8 & $\begin{array}{l}\text { Sife, Lwoga, \& } \\
\text { Sanga (2007) }\end{array}$ & $\begin{array}{l}\text { New technologies for } \\
\text { teaching and learning: } \\
\text { Challenges for higher } \\
\text { learning institutions in } \\
\text { developing countries }\end{array}$ & IJE\&DUICT & Tanzania \\
\hline 2 & 134 & 16.8 & $\begin{array}{l}\text { EL-Deghaidy \& } \\
\text { Nouby (2008) }\end{array}$ & $\begin{array}{l}\text { Effectiveness of a } \\
\text { blended e-learning } \\
\text { cooperative approach in } \\
\text { an Egyptian teacher } \\
\text { education programme }\end{array}$ & $C \& E$ & Egypt \\
\hline 3 & 105 & 8.8 & $\begin{array}{l}\text { Cox, Carr, \& Hall } \\
\text { (2004) }\end{array}$ & $\begin{array}{l}\text { Evaluating the use of } \\
\text { synchronous } \\
\text { communication in two } \\
\text { blended courses }\end{array}$ & $J C A L$ & $\begin{array}{l}\text { South } \\
\text { Africa }\end{array}$ \\
\hline 4 & 32 & 6.4 & Cronje (2011) & $\begin{array}{l}\text { Using Hofstede's cultural } \\
\text { dimensions to interpret } \\
\text { cross-cultural blended } \\
\text { teaching and learning }\end{array}$ & $E T \& S$ & $\begin{array}{l}\text { Sudan \& } \\
\text { South } \\
\text { Africa }\end{array}$ \\
\hline 5 & 31 & 4.4 & $\begin{array}{l}\text { Boitshwarelo } \\
\text { (2009) }\end{array}$ & $\begin{array}{l}\text { Exploring blended } \\
\text { learning for science } \\
\text { teacher professional } \\
\text { development in an } \\
\text { African context }\end{array}$ & IRRODL & Botswana \\
\hline 6 & 28 & 3.1 & $\begin{array}{l}\text { Prinsloo \& Van } \\
\text { Rooyen (2007) }\end{array}$ & $\begin{array}{l}\text { Exploring a blended } \\
\text { learning approach to } \\
\text { improving student } \\
\text { success in the teaching of } \\
\text { second year accounting }\end{array}$ & $\begin{array}{l}\text { Electronic } \\
\text { Journal of E- } \\
\text { learning }\end{array}$ & $\begin{array}{l}\text { South } \\
\text { Africa }\end{array}$ \\
\hline 7 & 27 & 4.5 & $\begin{array}{l}\text { Bozalek \& } \\
\text { Biersteker (2010) }\end{array}$ & $\begin{array}{l}\text { Exploring power and } \\
\text { privilege using } \\
\text { participatory learning } \\
\text { and action techniques }\end{array}$ & $\begin{array}{l}\text { Social Work } \\
\text { Education }\end{array}$ & $\begin{array}{l}\text { South } \\
\text { Africa }\end{array}$ \\
\hline 8 & 24 & 6.0 & $\begin{array}{l}\text { Ng'ambi, Lombe, } \\
\text { \& Ng (2012) }\end{array}$ & $\begin{array}{l}\text { Using Podcasting to } \\
\text { Facilitate Student } \\
\text { Learning: A } \\
\text { Constructivist } \\
\text { Perspective }\end{array}$ & $\begin{array}{l}\text { Educational } \\
\text { Technology \& } \\
\text { Society }\end{array}$ & $\begin{array}{l}\text { South } \\
\text { Africa }\end{array}$ \\
\hline 9 & 19 & 2.2 & Pineteh (2012) & $\begin{array}{l}\text { Using virtual interactions } \\
\text { to enhance the teaching } \\
\text { of communication skill } \\
\text { to information } \\
\text { technology students. }\end{array}$ & BJET & $\begin{array}{l}\text { South } \\
\text { Africa }\end{array}$ \\
\hline 10 & 18 & 2.0 & $\begin{array}{l}\text { Bozalek et al. } \\
\text { (2008) }\end{array}$ & $\begin{array}{l}\text { Students learning across } \\
\text { differences in a multi- } \\
\text { disciplinary virtual } \\
\text { learning community }\end{array}$ & $\begin{array}{l}\text { South African } \\
\text { Journal of } \\
\text { Higher } \\
\text { Education }\end{array}$ & $\begin{array}{l}\text { South } \\
\text { Africa }\end{array}$ \\
\hline
\end{tabular}


Table A.2

10 most cited articles in Asia

\begin{tabular}{|c|c|c|c|c|c|c|}
\hline \# & $\begin{array}{l}\text { New } \\
\text { cites }\end{array}$ & $\begin{array}{c}\mathrm{Av} \\
\text { cites/yr }\end{array}$ & Authors & Title & Source & Country \\
\hline 1 & 256 & 42.7 & $\begin{array}{l}\text { Wu, Tennyson, } \\
\& \text { Hsia (2010) }\end{array}$ & $\begin{array}{l}\text { A study of student satisfaction } \\
\text { in a blended e-learning system } \\
\text { environment }\end{array}$ & $C \& E$ & Taiwan \\
\hline 2 & 200 & 28.6 & $\begin{array}{l}\text { Wang, Shen, } \\
\text { Novak, \&Pan } \\
\text { (2009) }\end{array}$ & $\begin{array}{l}\text { The impact of mobile learning } \\
\text { on students' learning behaviors } \\
\text { and performance: Report from } \\
\text { a large blended classroom }\end{array}$ & BJET & China \\
\hline 3 & 156 & 26.0 & $\begin{array}{l}\text { Miyazoe \& } \\
\text { Anderson } \\
(2010)\end{array}$ & $\begin{array}{l}\text { Learning outcomes and } \\
\text { students' perceptions of online } \\
\text { writing: Simultaneous } \\
\text { implementation of a forum, } \\
\text { blog, and wiki in an EFL } \\
\text { blended learning setting }\end{array}$ & System & Japan \\
\hline 4 & 115 & 23.0 & Shih (2011) & $\begin{array}{l}\text { Can Web } 2.0 \text { technology assist } \\
\text { college students in learning } \\
\text { English writing? Integrating } \\
\text { Facebook and peer assessment } \\
\text { with blended learning }\end{array}$ & AJET & Taiwan \\
\hline 5 & 98 & 10.9 & $\begin{array}{l}\text { Bhattacharya } \\
\text { \& Sharma } \\
\text { (2007) }\end{array}$ & $\begin{array}{l}\text { India in the knowledge } \\
\text { economy an electronic } \\
\text { paradigm }\end{array}$ & IJEM & India \\
\hline 6 & 81 & 10.1 & $\begin{array}{l}\text { Sung, Kwon, } \\
\text { \& Ryu (2008) }\end{array}$ & $\begin{array}{l}\text { Blended learning on } \\
\text { medication administration for } \\
\text { new nurses: Integration of e- } \\
\text { learning and face-to-face } \\
\text { instruction in the classroom }\end{array}$ & $\begin{array}{l}\text { Nurse } \\
\text { Education } \\
\text { Today }\end{array}$ & $\begin{array}{l}\text { South } \\
\text { Korea }\end{array}$ \\
\hline 7 & 62 & 4.8 & $\begin{array}{l}\text { Khine \& } \\
\text { Lourdusamy } \\
\text { (2003) }\end{array}$ & $\begin{array}{l}\text { Blended learning approach in } \\
\text { teacher education: Combining } \\
\text { face-to-face instruction, } \\
\text { multimedia viewing and online } \\
\text { discussion }\end{array}$ & BJET & Singapore \\
\hline 8 & 60 & 7.5 & $\begin{array}{l}\text { Shen, Wang, \& } \\
\text { Pan (2008) }\end{array}$ & $\begin{array}{l}\text { Increasing interactivity in } \\
\text { blended classrooms through a } \\
\text { cutting-edge mobile learning } \\
\text { system }\end{array}$ & BJET & China \\
\hline 9 & 49 & 8.2 & $\begin{array}{l}\text { Sanprasert } \\
(2010)\end{array}$ & $\begin{array}{l}\text { The application of a course } \\
\text { management system to } \\
\text { enhance autonomy in learning } \\
\text { English as a foreign language }\end{array}$ & System & Thailand \\
\hline 10 & 41 & 4.1 & $\begin{array}{l}\text { Keppell \& } \\
\text { Carless (2006) }\end{array}$ & $\begin{array}{l}\text { Learning oriented assessment: } \\
\text { A technology based case study }\end{array}$ & $\begin{array}{l}\text { Assessment in } \\
\text { Education: } \\
\text { Principles, } \\
\text { Policy \& } \\
\text { Practice }\end{array}$ & China \\
\hline
\end{tabular}


Table A.3

10 most cited articles in Europe

\begin{tabular}{|c|c|c|c|c|c|c|}
\hline \# & $\begin{array}{l}\text { Total } \\
\text { cites }\end{array}$ & $\begin{array}{c}\mathrm{Av} \\
\text { cites/yr }\end{array}$ & Authors & Title & Source & Country \\
\hline 1 & 541 & 49.2 & $\begin{array}{l}\text { Oliver \& } \\
\text { Trigwell (2005) }\end{array}$ & $\begin{array}{l}\text { Can "blended learning” be } \\
\text { redeemed? }\end{array}$ & E-Learning & $\begin{array}{l}\text { United } \\
\text { Kingdom \& } \\
\text { Netherlands }\end{array}$ \\
\hline 2 & 348 & 31.6 & $\begin{array}{l}\text { Alonso, Lopez, } \\
\text { Manrique, } \\
\text { \&Vines (2005) }\end{array}$ & $\begin{array}{l}\text { An instructional model for } \\
\text { web-based e-learning } \\
\text { education with a blended } \\
\text { learning process approach }\end{array}$ & BJET & Spain \\
\hline 3 & 258 & 19.8 & $\begin{array}{l}\text { Kerres \&De } \\
\text { Witt (2003) }\end{array}$ & $\begin{array}{l}\text { A didactical framework } \\
\text { for the design of blended } \\
\text { learning }\end{array}$ & $J E M$ & Germany \\
\hline 4 & 245 & 22.3 & $\begin{array}{l}\text { Concannon, } \\
\text { Flynn, \& } \\
\text { Campbell } \\
\text { (2005) }\end{array}$ & $\begin{array}{l}\text { What campus- based } \\
\text { students think about the } \\
\text { quality and benefits of e- } \\
\text { learning }\end{array}$ & BJET & Ireland \\
\hline 5 & 198 & 28.3 & $\begin{array}{l}\text { Hoic-Bozic, } \\
\text { Mornar, \& } \\
\text { Boticki (2009) }\end{array}$ & $\begin{array}{l}\text { A blended learning } \\
\text { approach to course design } \\
\text { and implementation }\end{array}$ & IEEE & Croatia \\
\hline 6 & 187 & 37.4 & $\begin{array}{l}\text { López-Pérez, } \\
\text { Pérez-López, \& } \\
\text { Rodríguez-Ariza } \\
\text { (2011) }\end{array}$ & $\begin{array}{l}\text { Blended Learning in } \\
\text { higher education: } \\
\text { Students' perceptions and } \\
\text { their relation to outcomes }\end{array}$ & $C \& E$ & Spain \\
\hline 7 & 186 & 20.7 & $\begin{array}{l}\text { Hall \& Davison } \\
\text { (2007) }\end{array}$ & $\begin{array}{l}\text { Social software as support } \\
\text { in hybrid learning } \\
\text { environments: The value } \\
\text { of the blog as a tool for } \\
\text { reflective learning and } \\
\text { peer support }\end{array}$ & $\begin{array}{l}\text { Library \& } \\
\text { Information } \\
\text { Science } \\
\text { Research }\end{array}$ & $\begin{array}{l}\text { United } \\
\text { Kingdom }\end{array}$ \\
\hline 8 & 184 & 16.7 & $\begin{array}{l}\text { Derntl } \\
\text { \&Motschnig- } \\
\text { Pitrik (2005) }\end{array}$ & $\begin{array}{l}\text { The role of structure, } \\
\text { patterns, and people in } \\
\text { blended learning }\end{array}$ & $I H E$ & Austria \\
\hline 9 & 183 & 14.1 & $\begin{array}{l}\text { Boyle, Bradley, } \\
\text { Chalk, Jones, \& } \\
\text { Pickard (2003) }\end{array}$ & $\begin{array}{l}\text { Using blended learning to } \\
\text { improve student success } \\
\text { rates in learning to } \\
\text { program }\end{array}$ & $J E M$ & $\begin{array}{l}\text { United } \\
\text { Kingdom }\end{array}$ \\
\hline 10 & 174 & 15.8 & $\begin{array}{l}\text { Taradi, Taradi, } \\
\text { Radic, \& } \\
\text { Pokrajac (2005) }\end{array}$ & $\begin{array}{l}\text { Blending problem-based } \\
\text { learning with Web } \\
\text { technology positively } \\
\text { impacts student learning } \\
\text { outcomes in acid-base } \\
\text { physiology }\end{array}$ & $\begin{array}{l}\text { Advances in } \\
\text { Physiology } \\
\text { Education }\end{array}$ & Croatia \\
\hline
\end{tabular}


Table A.4

10 most cited articles in Latin America

\begin{tabular}{|c|c|c|c|c|c|c|}
\hline \# & $\begin{array}{l}\text { Total } \\
\text { cites }\end{array}$ & $\begin{array}{c}\text { Av. } \\
\text { cites/yr }\end{array}$ & Authors & Title & Source & Country \\
\hline 1 & 166 & 16.6 & $\begin{array}{l}\text { Mortera-Gutiérrez } \\
\text { (2006) }\end{array}$ & $\begin{array}{l}\text { Faculty best practices } \\
\text { using blended learning } \\
\text { in e-learning and face- } \\
\text { to-face instruction }\end{array}$ & $\begin{array}{l}\text { international } \\
\text { Journal of E- } \\
\text { Learning }\end{array}$ & Mexico \\
\hline 2 & 117 & 11.7 & $\begin{array}{l}\text { Banados \& Ba } \\
\text { (2006) }\end{array}$ & $\begin{array}{l}\text { A blended-learning } \\
\text { pedagogical model for } \\
\text { teaching and learning } \\
\text { EFL successfully } \\
\text { multimedia } \\
\text { environment }\end{array}$ & Calico Journal & Chile \\
\hline 3 & 6 & 1.2 & Llambi et al. (2011) & $\begin{array}{l}\text { Teaching tobacco } \\
\text { cessation skills to } \\
\text { Uruguayan physicians } \\
\text { using information and } \\
\text { communication }\end{array}$ & $\begin{array}{l}\text { Journal of } \\
\text { Continuing } \\
\text { Education in the } \\
\text { Health } \\
\text { Professions }\end{array}$ & Uruguay \\
\hline 4 & 5 & 1.0 & $\begin{array}{l}\text { Garrote, Pettersson, } \\
\text { \& Christie (2011) }\end{array}$ & $\begin{array}{l}\text { LiveUSB mediated } \\
\text { education: A method to } \\
\text { facilitate computer } \\
\text { supported education }\end{array}$ & AJET & $\begin{array}{l}\text { Cuba, } \\
\text { Guatemala } \\
\text { \& Peru }\end{array}$ \\
\hline 5 & 4 & 0.7 & $\begin{array}{l}\text { de Espíndola et al. } \\
\text { (2010) }\end{array}$ & $\begin{array}{l}\text { Teaching energy } \\
\text { metabolism using } \\
\text { scientific articles: } \\
\text { Implementation of a } \\
\text { virtual learning } \\
\text { environment for } \\
\text { medical students. }\end{array}$ & $\begin{array}{l}\text { Biochemistry } \\
\text { and Molecular } \\
\text { Biology } \\
\text { Education }\end{array}$ & Brazil \\
\hline 6 & 3 & 0.8 & $\begin{array}{l}\text { Peixoto, Peixoto, \& } \\
\text { Alves (2012) }\end{array}$ & $\begin{array}{l}\text { Learning strategies used } \\
\text { by undergraduate and } \\
\text { postgraduate students in } \\
\text { hybrid courses in the } \\
\text { area of health. }\end{array}$ & $\begin{array}{l}\text { Revista latino- } \\
\text { americana de } \\
\text { enfermagem }\end{array}$ & Brazil \\
\hline
\end{tabular}


Table A.5

10 most cited articles in Middle East

\begin{tabular}{|c|c|c|c|c|c|c|}
\hline \# & $\begin{array}{l}\text { Total } \\
\text { cites }\end{array}$ & $\begin{array}{c}\text { Av } \\
\text { cites/yr }\end{array}$ & Authors & Title & Source & Country \\
\hline 1 & 252 & 36.0 & $\begin{array}{l}\text { Ozkan \& } \\
\text { Koseler (2009) }\end{array}$ & $\begin{array}{l}\text { Multi-dimensional students' } \\
\text { evaluation of e-learning } \\
\text { systems in the higher } \\
\text { education context: An } \\
\text { empirical investigation }\end{array}$ & $C \& E$ & Turkey \\
\hline 2 & 144 & 18.0 & $\begin{array}{l}\text { Akkoyunlu \& } \\
\text { Soylu (2008) }\end{array}$ & $\begin{array}{l}\text { A study of students; Views } \\
\text { about blended learning } \\
\text { environment }\end{array}$ & $E T \& S$ & Turkey \\
\hline 3 & 94 & 10.4 & $\begin{array}{l}\text { Delialioglu \& } \\
\text { Yildirim (2007) }\end{array}$ & $\begin{array}{l}\text { Students' perceptions on } \\
\text { effective dimensions of } \\
\text { interactive learning in a } \\
\text { blended learning environmnent }\end{array}$ & $E T \& S$ & Turkey \\
\hline 4 & 76 & 15.2 & Ocak (2011) & $\begin{array}{l}\text { Why are faculty members not } \\
\text { teaching blended courses? } \\
\text { Insights from faculty members }\end{array}$ & $C \& E$ & Turkey \\
\hline 5 & 64 & 9.1 & $\begin{array}{l}\text { Precel, Eshet- } \\
\text { Alkalai, \& } \\
\text { Alberton (2009) }\end{array}$ & $\begin{array}{l}\text { Pedagogical and design } \\
\text { aspects of a blended learning } \\
\text { course }\end{array}$ & IRRODL & Israel \\
\hline 6 & 25 & 3.1 & Jamlan (2004) & $\begin{array}{l}\text { Faculty opinions towards } \\
\text { introducing e-learning at the } \\
\text { University of Bahrain }\end{array}$ & $I R R O D L$ & Bahrain \\
\hline 7 & 37 & 3.1 & $\begin{array}{l}\text { Korkmaz \& } \\
\text { Krakaus (2009) }\end{array}$ & $\begin{array}{l}\text { The impact of blended } \\
\text { learning model on student } \\
\text { attitudes towards geography } \\
\text { course and their critical } \\
\text { thinking dispositions and } \\
\text { levels }\end{array}$ & TOJDE & Turkey \\
\hline 8 & 34 & 4.9 & $\begin{array}{l}\text { Gulbahar \& } \\
\text { Madran (2009) }\end{array}$ & $\begin{array}{l}\text { Communication and } \\
\text { collaboration satisfaction, } \\
\text { equity, and autonomy in } \\
\text { blended learning } \\
\text { environments: A case from } \\
\text { Turkey }\end{array}$ & IRRODL & Turkey \\
\hline 9 & 32 & 4.6 & Kırkgöz (2011) & $\begin{array}{l}\text { A Blended Learning Study on } \\
\text { Implementing Video Recorded } \\
\text { Speaking Tasks in Task-Based } \\
\text { Classroom Instruction }\end{array}$ & TOJET & Turkey \\
\hline 10 & 26 & 5.2 & $\begin{array}{l}\text { Berger, Eylon, } \\
\text { \& Bagno (2008) }\end{array}$ & & $\begin{array}{l}\text { Journal of } \\
\text { Science } \\
\text { Education and } \\
\text { Technology }\end{array}$ & Israel \\
\hline
\end{tabular}


Table A.6

10 most cited articles in North America

\begin{tabular}{|c|c|c|c|c|c|c|}
\hline$\#$ & $\begin{array}{l}\text { Total } \\
\text { cites }\end{array}$ & $\begin{array}{c}\mathrm{Av} \\
\text { cites/yr }\end{array}$ & Authors & Title & Source & Country \\
\hline 1 & 1699 & 141.6 & $\begin{array}{l}\text { Garrison \& Kanuka } \\
\text { (2004) }\end{array}$ & $\begin{array}{l}\text { Blended learning: } \\
\text { Uncovering its } \\
\text { transformative potential in } \\
\text { higher education }\end{array}$ & IHE & Canada \\
\hline 2 & 1034 & 103.4 & $\begin{array}{l}\text { Ruiz, Mintzer, \& } \\
\text { Leipzig (2006) }\end{array}$ & $\begin{array}{l}\text { The impact of e-learning in } \\
\text { medical education }\end{array}$ & $\begin{array}{l}\text { Academic } \\
\text { Medicine }\end{array}$ & $\begin{array}{l}\text { United } \\
\text { States }\end{array}$ \\
\hline 3 & 805 & 61.9 & $\begin{array}{l}\text { Osguthorpe \& } \\
\text { Graham (2003) }\end{array}$ & $\begin{array}{l}\text { Blended learning } \\
\text { environments: Definitions } \\
\text { and directions }\end{array}$ & $\begin{array}{l}\text { Quarterly } \\
\text { Review of } \\
\text { Distance } \\
\text { Education }\end{array}$ & $\begin{array}{l}\text { United } \\
\text { States }\end{array}$ \\
\hline 4 & 717 & 55.2 & Singh (2003) & $\begin{array}{l}\text { Building effective blended } \\
\text { learning programs }\end{array}$ & $\begin{array}{l}\text { Educational } \\
\text { Technology }\end{array}$ & $\begin{array}{l}\text { United } \\
\text { States }\end{array}$ \\
\hline 5 & 596 & 49.7 & $\begin{array}{l}\text { Rovai \& Jordan } \\
(2004)\end{array}$ & $\begin{array}{l}\text { Blended learning and sense } \\
\text { of community: A } \\
\text { comparative analysis with } \\
\text { traditional and fully online } \\
\text { graduate courses }\end{array}$ & IRRODL & $\begin{array}{l}\text { United } \\
\text { States }\end{array}$ \\
\hline 6 & 408 & 40.8 & Kim \& Bonk (2006) & $\begin{array}{l}\text { The future of online } \\
\text { teaching and learning in } \\
\text { higher education: The } \\
\text { survey says }\end{array}$ & $\begin{array}{l}\text { Educause } \\
\text { Quarterly }\end{array}$ & $\begin{array}{l}\text { United } \\
\text { States }\end{array}$ \\
\hline 7 & 379 & 54.1 & Bernard et al. (2009) & $\begin{array}{l}\text { A meta-analysis of three } \\
\text { types of interaction } \\
\text { treatments in distance } \\
\text { education }\end{array}$ & $\begin{array}{l}\text { Review of } \\
\text { Educational } \\
\text { Research }\end{array}$ & Canada \\
\hline 8 & 334 & 37.1 & $\begin{array}{l}\text { Picciano \& Seaman } \\
\text { (2007) }\end{array}$ & $\begin{array}{l}\text { K-12 online learning: A } \\
\text { survey of U.S. school } \\
\text { district administrators }\end{array}$ & $J A L N$ & $\begin{array}{l}\text { United } \\
\text { States }\end{array}$ \\
\hline 9 & 312 & 22.3 & $\begin{array}{l}\text { Brown \& Liedholm } \\
\text { (2002) }\end{array}$ & $\begin{array}{l}\text { Can web courses replace } \\
\text { the classroom in principles } \\
\text { of microeconomics? }\end{array}$ & $\begin{array}{l}\text { The American } \\
\text { Economic } \\
\text { Review }\end{array}$ & $\begin{array}{l}\text { United } \\
\text { States }\end{array}$ \\
\hline 10 & 309 & 28.1 & $\begin{array}{l}\text { Bourne, Harris, \& } \\
\text { Mayadas (2005) }\end{array}$ & $\begin{array}{l}\text { Online engineering } \\
\text { education: Learning } \\
\text { anywhere, anytime }\end{array}$ & $\begin{array}{l}\text { Journal of } \\
\text { Engineering } \\
\text { Education }\end{array}$ & $\begin{array}{l}\text { United } \\
\text { States }\end{array}$ \\
\hline
\end{tabular}


Table A.7

10 most cited articles in Oceania

\begin{tabular}{|c|c|c|c|c|c|c|}
\hline \# & $\begin{array}{l}\text { Total } \\
\text { cites }\end{array}$ & $\begin{array}{c}\mathrm{Av} \\
\text { cites/yr }\end{array}$ & Authors & Title & Source & Country \\
\hline 1 & 260 & 28.9 & $\begin{array}{l}\text { Ginns \& Ellis } \\
\text { (2007) }\end{array}$ & $\begin{array}{l}\text { Quality in blended learning: } \\
\text { Exploring the relationships } \\
\text { between on-line and face-to- } \\
\text { face teaching and learning }\end{array}$ & IHE & Australia \\
\hline 2 & 202 & 22.4 & $\begin{array}{l}\text { Bluic, } \\
\text { Goodyear, \& } \\
\text { Ellis (2007) }\end{array}$ & $\begin{array}{l}\text { Research focus and } \\
\text { methodological choices in } \\
\text { studies into students' } \\
\text { experiences of blended } \\
\text { learning in higher education }\end{array}$ & IHE & Australia \\
\hline 3 & 106 & 15.1 & $\begin{array}{l}\text { Neumann \& } \\
\text { Hood (2009) }\end{array}$ & $\begin{array}{l}\text { The effects of using a wiki } \\
\text { on student engagement and } \\
\text { learning of report writing } \\
\text { skills in a university } \\
\text { statistics course }\end{array}$ & AJET & Australia \\
\hline 4 & 90 & 15.0 & $\begin{array}{l}\text { DeGeorge- } \\
\text { Walker \& } \\
\text { Keeffe (2010) }\end{array}$ & $\begin{array}{l}\text { Self determined blended } \\
\text { learning: A case study of } \\
\text { blended learning design }\end{array}$ & $\begin{array}{l}\text { Higher } \\
\text { Education } \\
\text { Research \& } \\
\text { Development }\end{array}$ & Australia \\
\hline 5 & 86 & 14.3 & $\begin{array}{l}\text { Benson \& } \\
\text { Samarawickrem } \\
\text { a (2009) }\end{array}$ & $\begin{array}{l}\text { Addressing the context of } \\
\text { learning: Using transactional } \\
\text { distance theory to inform } \\
\text { design }\end{array}$ & $D E$ & Australia \\
\hline 6 & 80 & 6.2 & $\begin{array}{l}\text { O'Toole \& } \\
\text { Absalom (2003) }\end{array}$ & $\begin{array}{l}\text { The impact of blended } \\
\text { learning on student } \\
\text { outcomes: Is there room on } \\
\text { the horse for two? }\end{array}$ & $J E M$ & Australia \\
\hline 6 & 80 & 10.0 & $\begin{array}{l}\text { Chandra \& } \\
\text { Lloyd (2008) }\end{array}$ & $\begin{array}{l}\text { The methodological nettle: } \\
\text { ICT and student } \\
\text { achievement }\end{array}$ & BJET & Australia \\
\hline 6 & 80 & 10.0 & $\begin{array}{l}\text { Goodyear \& } \\
\text { Ellis (2008) }\end{array}$ & $\begin{array}{l}\text { University students' } \\
\text { approaches to learning: } \\
\text { Rethinking the place of } \\
\text { technology }\end{array}$ & $D E$ & Australia \\
\hline 9 & 75 & 9.4 & $\begin{array}{l}\text { Dantas \& Kemm } \\
\text { (2008) }\end{array}$ & $\begin{array}{l}\text { A blended approach to } \\
\text { active learning in a } \\
\text { physiology laboratory-based } \\
\text { subject facilitated by an e- } \\
\text { learning component }\end{array}$ & $\begin{array}{l}\text { Advances in } \\
\text { physiology } \\
\text { education }\end{array}$ & Australia \\
\hline 10 & 66 & 7.3 & $\begin{array}{l}\text { Ellis, Goodyear, } \\
\text { O'Hara, \& } \\
\text { Prosser (2007) }\end{array}$ & $\begin{array}{l}\text { The university student } \\
\text { experience of face-to-face } \\
\text { and online discussions: } \\
\text { Coherence, reflection and } \\
\text { meaning }\end{array}$ & $\begin{array}{l}\text { Alt-J: Research } \\
\text { in Learning } \\
\text { Technology }\end{array}$ & Australia \\
\hline
\end{tabular}


Table A.8

10 most cited articles involving multiple regions

\begin{tabular}{|c|c|c|c|c|c|c|}
\hline \# & $\begin{array}{l}\text { Total } \\
\text { cites }\end{array}$ & $\begin{array}{c}\text { Av. } \\
\text { cites/yr }\end{array}$ & Authors & Title & Source & Country \\
\hline 1 & 408 & 51.0 & $\begin{array}{l}\text { So \& Brush } \\
\text { (2008) }\end{array}$ & $\begin{array}{l}\text { Student perceptions of collaborative } \\
\text { learning, social presence and } \\
\text { satisfaction in a blended learning } \\
\text { environment: Relationships and } \\
\text { critical factors }\end{array}$ & $C \& E$ & $\begin{array}{l}\text { United } \\
\text { States, } \\
\text { Singapore }\end{array}$ \\
\hline 2 & 235 & 47.0 & $\begin{array}{l}\text { Gikandi et } \\
\text { al. (2011) }\end{array}$ & $\begin{array}{l}\text { Online formative assessment in } \\
\text { higher education: A review of the } \\
\text { literature }\end{array}$ & $C \& E$ & $\begin{array}{l}\text { Kenya \& } \\
\text { New } \\
\text { Zealand }\end{array}$ \\
\hline 3 & 185 & 18.5 & $\begin{array}{l}\text { Ellis, } \\
\text { Goodyear, } \\
\text { Prosser, \& } \\
\text { O'Hara } \\
(2006)\end{array}$ & $\begin{array}{l}\text { How and what university students } \\
\text { learn through online and face } \\
\text { face discussion: Conceptions, } \\
\text { intentions and approaches }\end{array}$ & $J C A L$ & $\begin{array}{l}\text { Australia \& } \\
\text { United } \\
\text { Kingdom }\end{array}$ \\
\hline 4 & 175 & 14.6 & $\begin{array}{l}\text { Lynch \& } \\
\text { Dembo } \\
\text { (2004) }\end{array}$ & $\begin{array}{l}\text { The relationship between self- } \\
\text { regulation and online learning in a } \\
\text { blended learning context }\end{array}$ & IRRODL & $\begin{array}{l}\text { South } \\
\text { Korea, } \\
\text { United } \\
\text { States }\end{array}$ \\
\hline 5 & 145 & 29.0 & $\begin{array}{l}\text { Akyol \& } \\
\text { Garrison } \\
\text { (2011) }\end{array}$ & $\begin{array}{l}\text { Understanding cognitive presence in } \\
\text { an online and blended community of } \\
\text { inquiry: Assessing outcomes and } \\
\text { processes for deep approaches to } \\
\text { learning }\end{array}$ & BJET & $\begin{array}{l}\text { Turkey \& } \\
\text { Canada }\end{array}$ \\
\hline 6 & 113 & 9.4 & $\begin{array}{l}\text { Unwin } \\
(2004)\end{array}$ & $\begin{array}{l}\text { Towards a framework for the use of } \\
\text { ICT in teacher training in Africa }\end{array}$ & $\begin{array}{l}\text { Open } \\
\text { Learning }\end{array}$ & $\begin{array}{l}\text { Multiple in } \\
\text { Africa \& } \\
\text { United } \\
\text { Kingdom }\end{array}$ \\
\hline 7 & 92 & 11.5 & $\begin{array}{l}\text { Ellis et al. } \\
\text { (2008) }\end{array}$ & $\begin{array}{l}\text { Engineering students' conceptions of } \\
\text { and approaches to learning through } \\
\text { discussions in face-to-face and } \\
\text { online contexts }\end{array}$ & $\begin{array}{l}\text { Learning } \\
\text { and } \\
\text { Instruction }\end{array}$ & $\begin{array}{l}\text { Australia \& } \\
\text { China }\end{array}$ \\
\hline 8 & 74 & 10.6 & $\begin{array}{l}\text { Oh \& Park } \\
\text { (2009) }\end{array}$ & $\begin{array}{l}\text { How are universities involved in } \\
\text { blended instruction? }\end{array}$ & $E T \& S$ & $\begin{array}{l}\text { Korea \& } \\
\text { several } \\
\text { others }\end{array}$ \\
\hline 9 & 69 & 11.5 & $\begin{array}{l}\text { So \& Bonk } \\
\text { (2010) }\end{array}$ & $\begin{array}{l}\text { Examining the Roles of Blended } \\
\text { Learning Approaches in Computer- } \\
\text { Supported Collaborative Learning ( } \\
\text { CSCL ) Environments : A Delphi } \\
\text { Study Blended Learning : From } \\
\text { Delivery Technology to Learning } \\
\text { Technology }\end{array}$ & $E T \& S$ & $\begin{array}{l}\text { Singapore, } \\
\text { United } \\
\text { States, } \\
\text { several } \\
\text { others }\end{array}$ \\
\hline 10 & 66 & 6.0 & $\begin{array}{l}\text { Pearson \& } \\
\text { Trinidad } \\
\text { (2005) }\end{array}$ & $\begin{array}{l}\text { OLES: An instrument for refining } \\
\text { the design of e-learning } \\
\text { environments }\end{array}$ & $J C A L$ & $\begin{array}{l}\text { Australia \& } \\
\text { China }\end{array}$ \\
\hline
\end{tabular}

